Marquette University

e-Publications@Marquette

$3-1-2012$

Photochemistry of Furyl- and Thienyldiazomethanes: Spectroscopic Characterization of Triplet 3-Thienylcarbene

Caroline R. Pharr

University of Wisconsin - Madison

Laura A. Kopff

University of Wisconsin - Madison

Brian Bennett

Medical College of Wisconsin

Scott Reid

Marquette University, scott.reid@marquette.edu

Robert J.McMahon

University of Wisconsin - Madison

Accepted version. Journal of the American Chemical Society, Vol. 134, No. 14 (March, 2012):

6443-6454. DOI. (C) 2012 American Chemical Society. Used with permission. 


\title{
Photochemistry of Furyl- and Thienyldiazomethanes: Spectroscopic Characterization of Triplet 3-Thienylcarbene
}

\author{
Caroline R. Pharr \\ Department of Chemistry, University of Wisconsin-Madison, \\ Madison, WI \\ Laura A. Kopff \\ Department of Chemistry, University of Wisconsin-Madison, \\ Madison, WI \\ Brian Bennett \\ National Biomedical EPR Center, Department of Biophysics, \\ Medical College of Wisconsin, \\ Milwaukee, WI \\ Scott A. Reid \\ Department of Chemistry, Marquette University, \\ Milwaukee, WI \\ Robert J. McMahon \\ Department of Chemistry, University of Wisconsin-Madison, \\ Madison, WI
}




\section{Abstract}
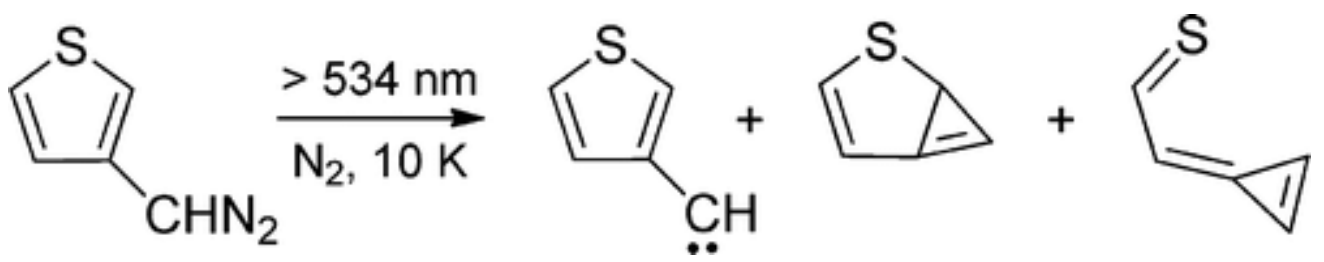

Photolysis ( $\lambda>543 \mathrm{~nm}$ ) of 3-thienyldiazomethane (1), matrix isolated in $\mathrm{Ar}$ or $\mathrm{N}_{2}$ at $10 \mathrm{~K}$, yields triplet 3-thienylcarbene (13) and a-thial-

methylenecyclopropene (9). Carbene $\mathbf{1 3}$ was characterized by IR, UV/vis, and EPR spectroscopy. The conformational isomers of 3-thienylcarbene ( $s-E$ and $s-Z$ ) exhibit an unusually large difference in zero-field splitting parameters in the triplet EPR spectrum $\left(|D / h c|=0.508 \mathrm{~cm}^{-1},|E / h c|=0.0554 \mathrm{~cm}^{-1} ;|D / h c|\right.$ $=0.579 \mathrm{~cm}^{-1},|E / h c|=0.0315 \mathrm{~cm}^{-1}$ ). Natural Bond Orbital (NBO) calculations reveal substantially differing spin densities in the 3-thienyl ring at the positions adjacent to the carbene center, which is one factor contributing to the large difference in $D$ values. NBO calculations also reveal a stabilizing interaction between the sp orbital of the carbene carbon in the $s-Z$ rotamer of 13 and the antibonding $\sigma$ orbital between sulfur and the neighboring carbonan interaction that is not observed in the $s-E$ rotamer of 13 . In contrast to the EPR spectra, the electronic absorption spectra of the rotamers of triplet 3thienylcarbene (13) are indistinguishable under our experimental conditions. The carbene exhibits a weak electronic absorption in the visible spectrum $\left(\lambda_{\max }=467 \mathrm{~nm}\right)$ that is characteristic of triplet arylcarbenes. Although studies of 2-thienyldiazomethane (2), 3-furyldiazomethane (3), or 2-

furyldiazomethane $(\mathbf{4})$ provided further insight into the photochemical interconversions among $\mathrm{C}_{5} \mathrm{H}_{4} \mathrm{~S}$ or $\mathrm{C}_{5} \mathrm{H}_{4} \mathrm{O}$ isomers, these studies did not lead to the spectroscopic detection of the corresponding triplet carbenes (2thienylcarbene (11), 3-furylcarbene (23), or 2-furylcarbene (22), respectively).

\section{Introduction}

The chemistry of aryl and heteroaryl carbenes constitutes a subject of longstanding interest in the field of organic reactive intermediates. ${ }^{1-3}$ Basic relationships concerning the structure, reactivity, and spectroscopy of these intermediates have been deduced through product analyses, matrix-isolation spectroscopy, time-resolved spectroscopy, and computational studies. For any given system, these relationships are strongly influenced by the electronic ground state of the carbene (singlet or triplet) and the magnitude of the singlet-triplet energy gap. In the singlet series, the chemistry and spectroscopy of arylchlorocarbenes (phenyl, ${ }^{4,5}$ pyridyl, ${ }^{6}$ furanyl, ${ }^{7,8}$ thienyl, ${ }^{9,10}$ and their benzo analogues) ${ }^{11-14}$ have been extensively investigated. Our own 
interest in arylcarbenes focuses on the triplet series because these species-lacking the halogen substituent-are more directly relevant to the harsh reaction environments encountered in combustion or in astrochemistry. ${ }^{15}$ That the chemistry of atomic carbon is important in astronomical environments invites attention to aryl- and heteroaryl carbenes, as these intermediates may be formed upon addition of a carbon atom to a stable, closed-shell aryl substrate. In the current study, we focus on the isomeric furyl- and thienylcarbenes, which have eluded detection and characterization to the present time. ${ }^{16,17}$ These fundamental studies of reactive thienyl intermediates are also germane to an understanding of the electronic structure of doped states of thiophene derivatives-materials that have achieved wide use in conducting polymers and other electronic applications. ${ }^{18-20}$

\section{Background}

Shechter and co-workers reported detailed product analyses associated with thermolysis of the isomeric thienyldiazomethanes ( 1 and $\mathbf{2}$ ) and furyldiazomethanes ( $\mathbf{3}$ and $\mathbf{4}$ ) (Scheme 1). ${ }^{21,22}$ The intermediacy of the corresponding thienyl- and furylcarbenes was inferred from the isolation of the products of insertion into the $\mathrm{C}-\mathrm{H}$ bond of cyclooctane and the formal products of dimerization. Fragmentation of the ring, to afford ring-opened products, was also observed. Shevlin and workers later postulated the intermediacy of 2and 3-thienylcarbene in the reaction of atomic ${ }^{13} \mathrm{C}$ with thiophene. ${ }^{23,24}$ Saito and co-workers devised intriguing systems in which the thermal furylcarbene fragmentation reaction is driven in the reverse direction under photochemical conditions. Thus, an acyclic enynal or enynone will undergo photocyclization to a 2-furylcarbene derivative, which can be trapped in either an inter- or intramolecular fashion. ${ }^{25}$ Thermal cyclization reactions of azo-ene-ynes are analogous, proceeding via a heteroaryl carbene intermediate. ${ }^{26-28}$ Albers and Sander elucidated key aspects of the photochemistry and spectroscopy of $\mathrm{C}_{5} \mathrm{H}_{4} \mathrm{~S}$ and $\mathrm{C}_{5} \mathrm{H}_{4} \mathrm{O}$ isomers through their study of the photochemistry of 3thienyldiazomethane (1), 3-furyldiazomethane (3), and 2furyldiazomethane (4) under matrix isolation conditions. ${ }^{16,17}$ None of the carbene intermediates, however, were detected. In terms of computational studies, McKee, Shevlin, and Zottola described an insightful, comprehensive study of the $\mathrm{C}_{5} \mathrm{H}_{4} \mathrm{~S}$ potential energy

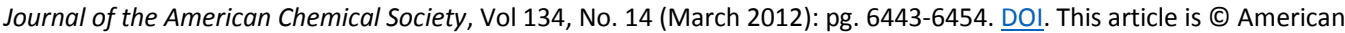
Chemical Society and permission has been granted for this version to appear in e-Publications@Marquette. American Chemical Society does not grant permission for this article to be further copied/distributed or hosted elsewhere without the express permission from American Chemical Society. 
surface. ${ }^{24}$ The mechanism of ring-opening of 2-furylcarbene, 2thienylcarbene, and related compounds has been the subject of several computational and theoretical investigations. ${ }^{7,24,29-31}$ Herges $^{29}$ described the reaction as a coarctate transformation, while Birney ${ }^{31}$ interpreted it as a pseudopericyclic process.

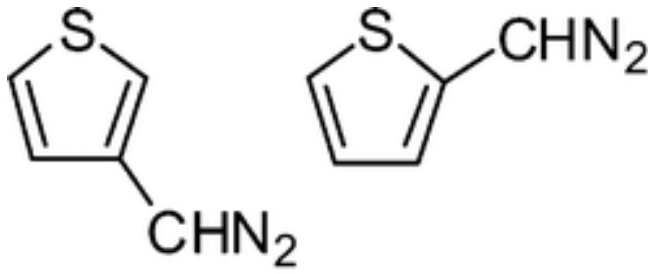

1

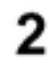

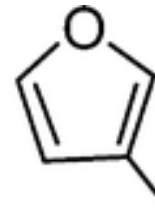

$\mathrm{CHN}_{2}$<smiles>N#Cc1ccco1</smiles>

Scheme 1. Thienyl and Furyldiazomethanes (1-4)

\section{Results}

Computed Energies of $\mathrm{C}_{5} \mathrm{H}_{4} \mathrm{~S}$ and $\mathrm{C}_{5} \mathrm{H}_{4} \mathrm{O}$ Isomers

To provide context for interpreting our experimental observations, we performed computational studies of the $\mathrm{C}_{5} \mathrm{H}_{4} \mathrm{~S}$ and $\mathrm{C}_{5} \mathrm{H}_{4} \mathrm{O}$ potential energy surfaces at the B3LYP/6-31G* level of theory. Structures and relative energies are depicted in Schemes 2 and 3, and additional details are provided as Supporting Information. This methodology is adequate for providing qualitatively reliable predictions of infrared spectra and relative energies across a range of molecular structures. In terms of relative energies, Density Functional Theory (DFT) methods often overemphasize delocalization in conjugated $n$-electron systems, ${ }^{32-34}$ and the B3LYP functional biases the calculation of singlet-triplet energy gaps by ca. $1-3 \mathrm{kcal} / \mathrm{mol}$ by underestimating the stability of the singlet, relative to the triplet. ${ }^{35,36}$ Because the singlettriplet energy gaps of the thienylcarbenes are of particular interest to us, we sought to corroborate the DFT predictions using ab initio methods. The results of coupled-cluster calculations, performed at a moderate level of theory (CCSD/cc-pVTZ), show good agreement with those obtained by using density functional theory for 2- and 3thienylcarbene (Scheme 4). Both computational methods predict a triplet electronic ground state for both carbenes. 
NOT THE PUBLISHED VERSION; this is the author's final, peer-reviewed manuscript. The published version may be accessed by following the link in the citation at the bottom of the page.

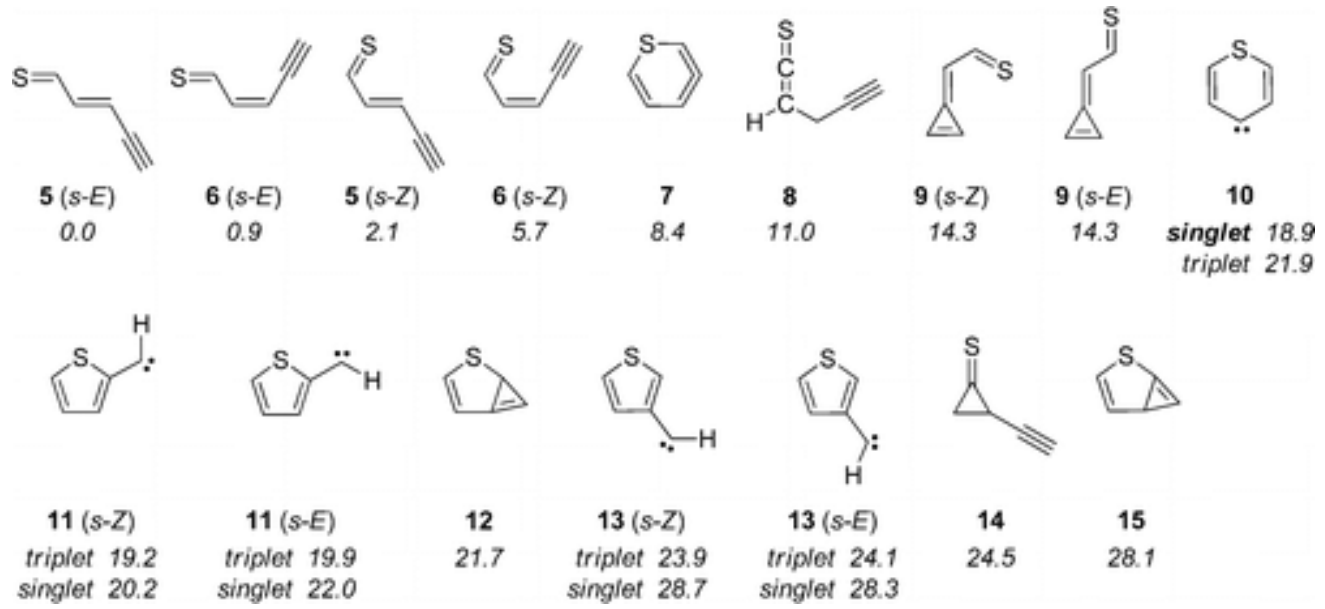

Scheme 2. $\mathrm{C}_{5} \mathrm{H}_{4} \mathrm{~S}$ Isomers and Their Computed Relative Energies ${ }^{\mathrm{a}}$

aEnergy (kcal/mol; ZPVE included). B3LYP/6-31G* level of theory.

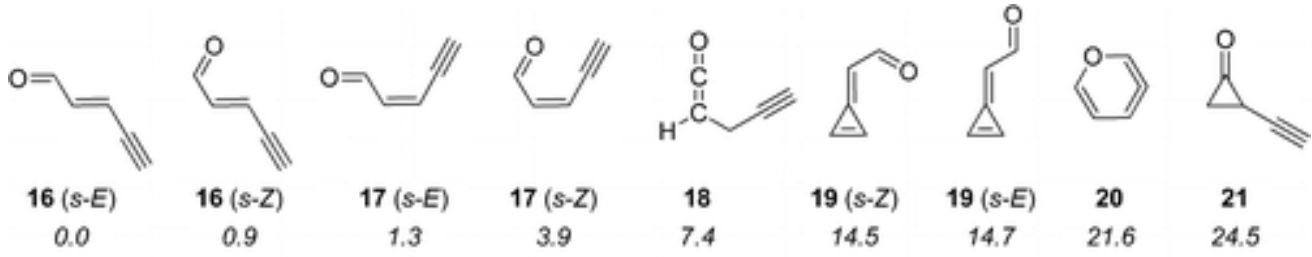

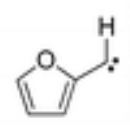

$22(s-Z)$ singlet 28.6 triplet 31.6

Scheme 3.
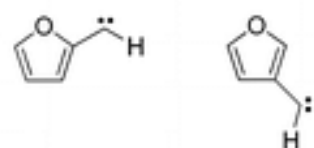
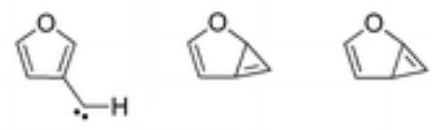

25

$$
23(s-Z)
$$

24

39.2

triplet 36.6 singlet 40.2

aEnergy (kcal/mol; ZPVE included). B3LYP/6-31G* level of theory.<smiles>c1ccsc1</smiles>

$11(s-Z)$

triplet 0.0 singlet 1.0

triplet 0.0 singlet 2.2<smiles>[CH]c1cccs1</smiles><smiles>C=Cc1ccsc1</smiles>

$13(s-Z)$<smiles>[TlH]c1ccsc1</smiles>

$13(s-E)$

\section{B3LYP/6-31G}

triplet $0.8 \quad$ triplet $4.8 \quad$ triplet 4.9

singlet $2.8 \quad$ singlet $9.5 \quad$ singlet 9.1

\section{CCSD/cc-pVTZ}

$\begin{array}{rrr}\text { triplet } 0.6 & \text { triplet } 3.2 & \text { triplet } 3.3 \\ \text { singlet } 3.0 & \text { singlet } 7.5 & \text { singlet } 7.0\end{array}$

Scheme 4. Thienylcarbenes and Their Computed Relative Energies ${ }^{a}$ aEnergy ( $\mathrm{kcal} / \mathrm{mol}$; ZPVE included).

Journal of the American Chemical Society, Vol 134, No. 14 (March 2012): pg. 6443-6454. DOI. This article is (C) American Chemical Society and permission has been granted for this version to appear in e-Publications@Marquette. American Chemical Society does not grant permission for this article to be further copied/distributed or hosted elsewhere without the express permission from American Chemical Society. 
Of the isomers that we investigated, the structurally analogous thioaldehyde $\mathbf{5}\left(\mathrm{C}_{5} \mathrm{H}_{4} \mathrm{~S}\right)$ and aldehyde $\mathbf{1 6}\left(\mathrm{C}_{5} \mathrm{H}_{4} \mathrm{O}\right)$ are the lowest energy structures on their respective potential energy surfaces. Portions of these surfaces have been investigated, previously, although the issue of conformational isomerism $(s-E, s-Z)$ in thioaldehydes (5, 6) or aldehydes $(\mathbf{1 6}, \mathbf{1 7})$ has not been explored in detail. ${ }^{16,17,24}$ The ( $s$ $Z$ ) rotamer is commonly drawn in mechanistic schemes, but there is only one case throughout the photochemistry of diazo compounds $\mathbf{1}$, $\mathbf{2}, \mathbf{3}$, and $\mathbf{4}$ where an $(s-Z)$ rotamer of any pentenyne $(s-Z-\mathbf{6})$ is actually observed in the matrix (see below). The computed IR spectra of the $(s-Z)$ and $(s-E)$ rotamers are quite different and allow clear analysis and differentiation of the peaks present in the experimental spectrum.

\section{Primary Photochemistry of 3-Thienyldiazomethane (1)}

Irradiation of 3-thienyldiazomethane (1) $\left(\lambda>534 \mathrm{~nm} ; \mathrm{N}_{2}, 10 \mathrm{~K}\right)$ gives a mixture of (s-Z)-a-thial-methylenecyclopropene $(\mathbf{9}),(s-E)-3-$ thienylcarbene $(s-E-13),(s-Z)-3$-thienylcarbene $(s-Z-13)$, and a minor amount of a species tentatively assigned as $1 \mathrm{H}-2-$

thiabicyclo[3.1.0] hexa-3,5-diene (12) (Scheme 5; Figure S1). ${ }^{37}$ IR assignments are based upon comparison of experimental spectra with computed IR spectra (B3LYP/6-31G*), as well as comparison with previously reported spectral data of $\mathbf{9}$ and 12. ${ }^{16,38}$ EPR and UV/Vis experiments, performed under analogous conditions, provide strong support for the assignment of triplet 3-thienylcarbene ( $s-E-$ and $s-Z-$ 13). The EPR spectrum of $\mathbf{1 3}$ affords direct evidence for the triplet species, and the spectroscopic features are generally consistent with those expected for an arylcarbene (Figure 1 ). ${ }^{39-41}$ A detailed analysis of the EPR spectrum will be provided as part of the Discussion section. The electronic absorption spectrum exhibits the weak visible absorption features that are characteristic of triplet aryl carbenes (and the benzyl radical) (Figure 2). ${ }^{39}$ The spectroscopic assignment of triplet 3-thienylcarbene (13) is further supported by the wavelengthdependent photochemistry, in which the IR, UV/vis, and EPR signals attributed to $\mathbf{1 3}$ disappear upon photoexcitation into the visible absorption feature at $\lambda_{\max }$ ca. $467 \mathrm{~nm}$ (Figures 2 and 3). 
NOT THE PUBLISHED VERSION; this is the author's final, peer-reviewed manuscript. The published version may be accessed by following the link in the citation at the bottom of the page.<smiles>N#Cc1ccsc1</smiles>

1<smiles>S=CC=C1CC1</smiles>

$9(s-Z)$<smiles>Cc1ccsc1</smiles><smiles>Cc1ccsc1</smiles>

$13(s-Z)$<smiles>c1csc2cccc-2c1</smiles>

12

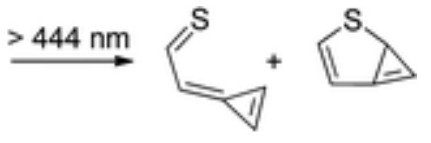

$9(s-Z) \quad 12$ $>363 \mathrm{~nm}$<smiles>C#CCC=C=S</smiles><smiles>C#C/C=C/C=S</smiles><smiles>C#C/C=C\C=S</smiles><smiles>S=CC=C1C=C1</smiles>

$>330 \mathrm{~nm}$<smiles>S=CC=C1C=C1</smiles>

8

$6(s-E) \quad 9(s-E)$

$9(s-E)$

Scheme 5. Photochemistry of 3-Thienyldiazomethane (1) $\left(\mathrm{N}_{2}, 10 \mathrm{~K}\right)$

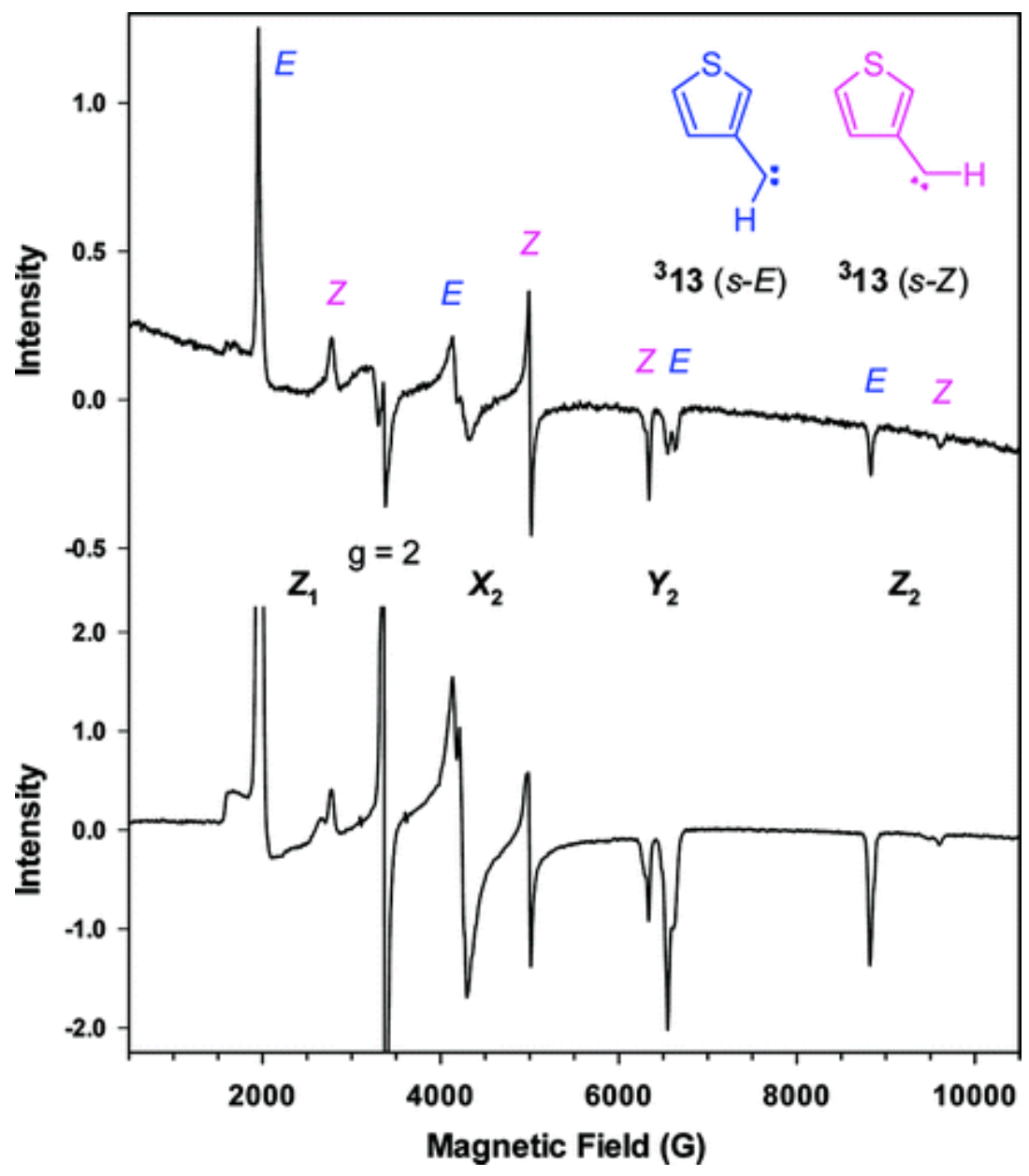

Figure 1. EPR spectra. Top: Spectrum of triplet $(s-E)$ and $(s-Z)$ 3-thienylcarbene (13), obtained upon irradiation $(\lambda>571 \mathrm{~nm}, 22 \mathrm{~h})$ of 3-thienyldiazomethane (1) (Ar, $15 \mathrm{~K})$. Bottom: Spectrum of triplet 13 obtained upon continued irradiation $(\lambda>571$ $\mathrm{nm}, 22 \mathrm{~h} ; \lambda>534 \mathrm{~nm}, 4.5 \mathrm{~h} ; \lambda>497 \mathrm{~nm}, 17.5 \mathrm{~h} ; \lambda>472 \mathrm{~nm}, 22.5 \mathrm{~h})$ of diazo compound 1. (Note difference in $y$-axis scales.)

Journal of the American Chemical Society, Vol 134, No. 14 (March 2012): pg. 6443-6454. DOI. This article is (C) American Chemical Society and permission has been granted for this version to appear in e-Publications@Marquette. American Chemical Society does not grant permission for this article to be further copied/distributed or hosted elsewhere without the express permission from American Chemical Society. 
NOT THE PUBLISHED VERSION; this is the author's final, peer-reviewed manuscript. The published version may be accessed by following the link in the citation at the bottom of the page.

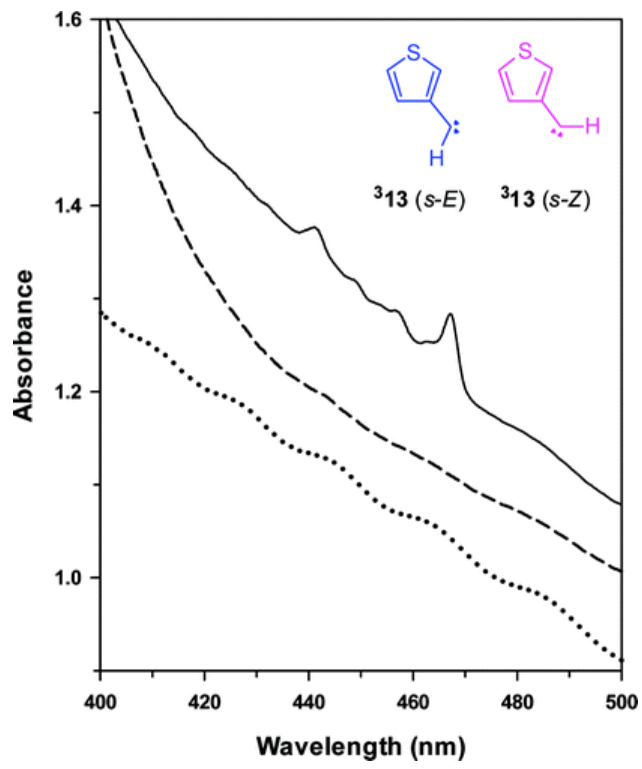

Figure 2. Electronic absorption spectra. Dotted line: Matrix containing (3thienyl)diazomethane (1) ( $\mathrm{Ar}, 10 \mathrm{~K}$ ) before irradiation. (The visible absorption of $\mathbf{1}$ is not observable because of the low concentration.) Solid line: Spectrum of $(s-E)$ and $(s-$ $Z$ ) triplet 3-thienylcarbene (13) observed upon photolysis of diazo compound $\mathbf{1}$ ( $\lambda>$ $472 \mathrm{~nm}, 19 \mathrm{~h})$. Dashed line: Spectrum showing the disappearance of carbenes $(s-E)-$ 13 and $(s-Z)-13$ upon irradiation $(\lambda>444 \mathrm{~nm}, 22 \mathrm{~h})$.

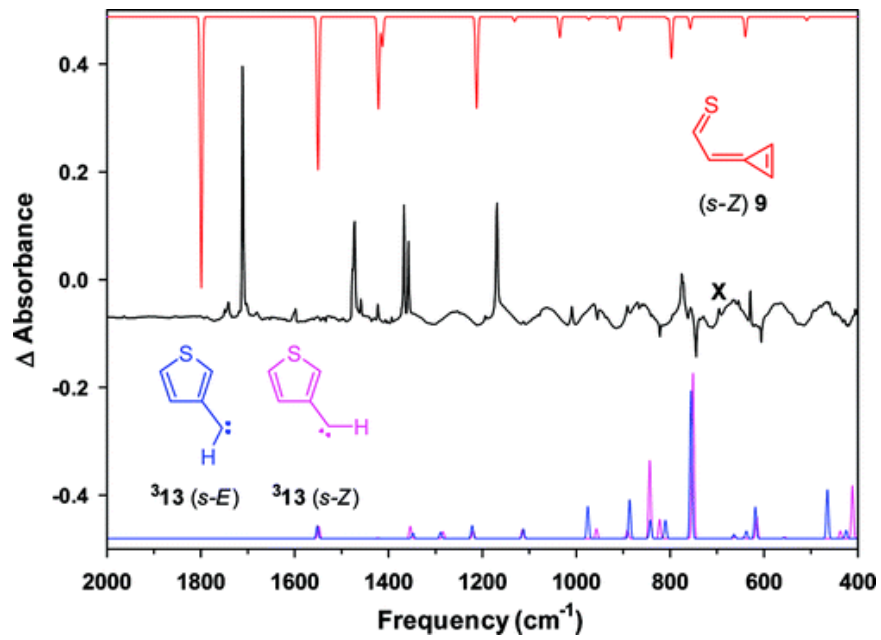

Figure 3. IR subtraction spectrum showing spectral changes observed upon selective irradiation $(\lambda=467 \pm 10 \mathrm{~nm}, 4 \mathrm{~h})$ of a matrix that contains a mixture of (3thienyl)diazomethane (1), $(s-Z)$-a-thial-methylenecyclopropene (9), $1 \mathrm{H}-2-$ thiabicyclo[3.1.0] hexa-3,5-diene (12), and triplet 3-thienylcarbene (13) $\left(\mathrm{N}_{2}, 10 \mathrm{~K}\right)$. The spectrum shows the disappearance of 3-thienylcarbene (13) and the growth of 9. Under these irradiation conditions, diazo compound $\mathbf{1}$ exhibits virtually no change in concentration, while bicyclic compound $\mathbf{1 2}$ displays only a very small increase $(\mathbf{X}=$ the major peak associated with 12). Computed IR spectra for both conformers of triplet 3-thienylcarbene (13) are superimposed at the bottom of the figure, while the computed IR spectrum for $(s-Z)-\mathbf{9}$ is shown at the top of the figure. 
Comparison of the electronic absorption spectra of 3thienyldiazomethane (1) and triplet 3-thienylcarbene (13) shows that diazo compound $\mathbf{1}$ absorbs at slightly longer wavelength (broad absorption with $\left.\lambda_{\max }=494 \mathrm{~nm}\right)$ than carbene $13\left(\lambda_{\max }=467 \mathrm{~nm}\right)$. (The 494-nm absorption of diazo compound $\mathbf{1}$, which was measured in acetonitrile solution, is not observable in the matrix spectrum depicted in Figure 2 because of the low concentration.) It is possible, therefore, to irradiate diazo compound $\mathbf{1}$ under long-wavelength, broadband conditions without inducing secondary photochemistry in the incipient 3-thienylcarbene (13). Long-wavelength irradiation of 3thienyldiazomethane (1) exhibits a subtle wavelength dependence, which we tentatively ascribe to differential photoreactivity of $s-E$ and $s-Z$ conformers of the diazo compound. Irradiation of diazo compound 1 at $\lambda>571 \mathrm{~nm}$ results in a mixture of $s-E$ and $s-Z$ conformers of triplet 3-thienylcarbene (13), with the $s-Z$ conformer growing more quickly, as measured by the greater intensity of the $X_{2}$ and $Y_{2}$ signals in the EPR spectrum (Figure 1 and Figure S8). Both conformers continue to grow upon irradiation at slightly shorter wavelength $(\lambda>$ $534,>497$, and $>472 \mathrm{~nm}$ ), but the $X_{2}$ and $Y_{2}$ signals of the $s-E$ conformer grow more quickly, such that the $s-E$ - conformer of triplet 3-thienylcarbene (13) becomes the major conformer in the EPR spectrum (Figure 1). Since both conformers appear to be stable to the irradiation conditions, and each disappears rapidly upon irradiation at $\lambda$ $>444 \mathrm{~nm}$ or $\lambda=467 \pm 10 \mathrm{~nm}$, we ascribe the differential rates of formation to the differential absorption and/or quantum yield for carbene formation from the conformational isomers of 3thienyldiazomethane (1). (TD-DFT calculations predict the electronic absorption spectra for the conformational isomers of 3thienyldiazomethane (1) to be similar (see the Supporting Information).)

With the EPR and visible spectra of triplet 3-thienylcarbene (13) in hand, we expended considerable effort in an attempt to optimize the experimental conditions to enhance the production of carbene $\mathbf{1 3}$ and/or minimize the formation of methylenecyclopropene derivative 9. (These efforts included extensive studies of the wavelength dependence of the photolysis of 3-thienyldiazomethane (1), as well as broad-band "flash" irradiation. $)^{42}$ Although our attempts were largely unsuccessful, they help us understand the photochemical reactivity of 
this system. An important observation is that the methylenecyclopropene derivative (9) is always formed, even under conditions where triplet 3-thienylcarbene (13) is stable to the irradiation conditions. Plausible mechanisms for the formation of $\mathbf{9}$, under these conditions, involve a hot ground-state reaction of carbene $\mathbf{1 3}$ or a reaction in the excited state of diazo compound $\mathbf{1}$. Both explanations have ample precedent in the field of carbene chemistry. The first mechanistic scenario posits that $\mathrm{N}_{2}$ loss from the excited state of 3-thienyldiazomethane (1) yields carbene $\mathbf{1 3}$ with excess vibrational energy, and that $\mathbf{9}$ arises from a hot ground-state reaction of carbene 13. To probe for the involvement of a hot ground-state carbene, we performed the photolysis of diazo compound $\mathbf{1}$ in $\mathrm{Ar}$ and $\mathrm{N}_{2}$ matrices, as well as a 2-methyltetrahydrofuran (2-MeTHF) glass. These media are increasingly effective in vibrational cooling of guest molecules, owing to an increasing density of vibrational states. ${ }^{43,44}$ We found, however, that the matrix medium does not influence the photochemistry, as judged by the fact that the intensity of the EPR signal of triplet 3-thienylcarbene (13) was not enhanced (relative to Ar) in either an $\mathrm{N}_{2}$ matrix or a 2-MeTHF glass. Thus, we do not favor the mechanism involving hot ground-state 3-thienylcarbene (13). Such an explanation would also seem to be at odds with the relatively high thermal barrier (>30 kcal/mol) separating singlet 3thienylcarbene (13) and a-thial-methylenecyclopropene (9). ${ }^{24}$ The more likely explanation, therefore, involves the excited state of the diazo compound. As observed in several other systems, ${ }^{45,46}$ the excited state of diazo compound $\mathbf{1}$ may partition between two pathways: $\mathrm{N}_{2}$ loss, to give 3-thienylcarbene (13), and $\mathrm{N}_{2}$ loss with concomitant rearrangement, to give a-thial-methylenecyclopropene (9) without the intervention of the carbene.

\section{Electronic Absorption Spectrum of Triplet 3- Thienylcarbene (13)}

3-Thienylcarbene (13) exhibits a weak electronic absorption in the visible region of the spectrum $\left(\lambda_{\max }=467 \mathrm{~nm}\right)$ that is characteristic of triplet arylcarbenes (and the benzyl radical) (Figure 2). ${ }^{39}$ The vibronic structure associated with the corresponding electronic transition in triplet phenylcarbene $\left(\lambda_{\max }=430 \mathrm{~nm}\right)$ has been analyzed in detail. ${ }^{47}$ Time-dependent density functional theory 
calculations (TD-DFT) do a reasonably good job of reproducing the general features of the absorption spectrum of triplet phenylcarbene (Table 1 ), although the energy of the visible excitation is overestimated. Analogous calculations for triplet 3-thienylcarbene (13) predict the visible absorption to be red-shifted relative to phenylcarbene (Table 1), in accord with experimental observation. The absorption spectra of the rotamers of triplet 3-thienylcarbene (13) are indistinguishable under our experimental conditions-a result that is also borne out by the TD-DFT calculations. In this respect, triplet 3thienylcarbene (13) is unlike the related singlet arylchlorocarbenes (furanyl, ${ }^{7,8}$ thienyl, ${ }^{9,10}$ and their benzo analogues), ${ }^{11-13}$ in which the absorption spectra of the conformational isomers exhibit significant differences. In the lowest singlet state, however, the absorption spectra of the conformers of 3-thienylcarbene are predicted to be readily distinguishable ( $\lambda_{\max } 995 \mathrm{~nm}$ vs $1045 \mathrm{~nm}$; Table 1 ).

Table 1. Computed Electronic Absorption Spectra of Carbenes ${ }^{a}$

\begin{tabular}{|c|c|c|c|c|c|c|c|}
\hline & $\begin{array}{r}(s-E \\
\text { car }\end{array}$ & $\begin{array}{l}\text {-3-thienyl } \\
\text { ene (13) }\end{array}$ & $\begin{array}{c}(s-Z) \\
\text { carl }\end{array}$ & $\begin{array}{l}\text {-3-thienyl } \\
\text { ene (13) }\end{array}$ & & $\begin{array}{l}\text { lenyl } \\
\text { rbene }\end{array}$ & $\begin{array}{l}\text { phenyl } \\
\text { carbene } \\
\text { (expt) }\end{array}$ \\
\hline & $\boldsymbol{\lambda}_{\max }$ & $f$ & $\boldsymbol{\lambda}_{\max }$ & $f$ & $\boldsymbol{\Lambda}_{\max }$ & $f$ & $\boldsymbol{\lambda}_{\max }$ \\
\hline triplet $\left(\mathrm{T}_{0}\right)$ & 388 & 0.0021 & 389 & 0.0020 & 373 & 0.0000 & 430 \\
\hline & 355 & 0.0022 & 356 & 0.0016 & 354 & 0.0012 & \\
\hline & 333 & 0.0006 & 337 & 0.0002 & 337 & 0.0015 & \\
\hline & 328 & 0.0006 & 328 & 0.0005 & 313 & 0.0001 & \\
\hline & 322 & 0.0196 & 322 & 0.0196 & 310 & 0.0324 & 300 \\
\hline & 321 & 0.0001 & 314 & 0.0002 & 306 & 0.0002 & \\
\hline & 295 & 0.0002 & 302 & 0.0010 & 274 & 0.0973 & \\
\hline & 278 & 0.1056 & 278 & 0.1045 & 243 & 0.1607 & 246 \\
\hline singlet $\left(S_{1}\right)$ & 995 & 0.0013 & 1045 & 0.0018 & 1140 & 0.0012 & \\
\hline & 316 & 0.0039 & 317 & 0.0001 & 320 & 0.0007 & \\
\hline & 307 & 0.0037 & 314 & 0.0111 & 311 & 0.0214 & \\
\hline & 303 & 0.0132 & 307 & 0.0098 & 308 & 0.0086 & \\
\hline & 285 & 0.0130 & 291 & 0.0007 & 285 & 0.0036 & \\
\hline & 278 & 0.0044 & 268 & 0.0279 & 272 & 0.0082 & \\
\hline & 256 & 0.1976 & 263 & 0.0549 & 271 & 0.0315 & \\
\hline & 252 & 0.0048 & 256 & 0.1549 & 260 & 0.2462 & \\
\hline
\end{tabular}

Journal of the American Chemical Society, Vol 134, No. 14 (March 2012): pg. 6443-6454. DOI. This article is (C) American Chemical Society and permission has been granted for this version to appear in e-Publications@Marquette. American Chemical Society does not grant permission for this article to be further copied/distributed or hosted elsewhere without the express permission from American Chemical Society. 


\section{Photochemistry of 3-Thienylcarbene (13) and Other $\mathrm{C}_{5} \mathrm{H}_{4} \mathrm{~S}$ Isomers}

Photoexcitation into the visible absorption feature $\left(\lambda_{\max }\right.$ ca. 467 $\mathrm{nm}$ ) of triplet 3-thienylcarbene (13), using either broadband ( $\lambda>444$ $\mathrm{nm}$ ) or narrow-band $(\lambda=467 \pm 10 \mathrm{~nm})$ irradiation conditions, leads to the rapid disappearance of the IR, UV/Vis, and EPR signals of carbene 13 and the growth of ( $(s-Z)$-a-thial-methylenecyclopropene (9), as well as the growth of a small amount of $1 \mathrm{H}$-2-thiabicyclo[3.1.0]hexa-3,5diene (12) (Figures 3 and S3). This behavior explains the inability of Albers and Sander to observe carbene $\mathbf{1 3}$ in their study of the photochemistry of 3-thienyldiazomethane (1). ${ }^{16}$ Our findings establish that carbene $\mathbf{1 3}$ is not stable to the photolysis conditions used in the earlier experiment $(\lambda>435 \mathrm{~nm})$.

The UV/vis spectrum of 9 exhibits an absorption at ca. 300-400 $\mathrm{nm}$ (Figure S11). Irradiation into this absorption feature $(\lambda>363 \mathrm{~nm})$ results in photoisomerization of the $s-Z$ conformer to the $s-E$ conformer (Figure S4). At slightly shorter wavelength $(\lambda>330 \mathrm{~nm})$, the IR bands of the $s-E$ conformer continue to grow, and the IR bands of the acyclic isomers, pent-2-en-4-ynethial (5 and 6), slowly appear (Figure S5). At $\lambda>280 \mathrm{~nm}$, another acyclic isomer, propargyl thioketene (8), appears in the IR spectrum, accompanied by the decrease in the IR absorptions of 5, 6, and $\mathbf{9}$ (Figure S6). Our findings corroborate those described earlier by Sander and co-workers, ${ }^{16}$ while adding some additional detail in terms of the conformational isomerism of pent-2-en-4-ynethial (5 and $\mathbf{6}$ ) and methylenecyclopropene derivatives (9). Our discovery of the shorter-wavelength chemistry that affords thioketene $\mathbf{8}$ is also new.

\section{Possible Thermal Chemistry of Triplet 3-Thienylcarbene (13)}

Allowing a matrix containing triplet 3-thienylcarbene (13) to stand in the dark at $15 \mathrm{~K}$ for an extended period of time (30-80 h) affords a small, but reproducible, decrease in the EPR signal of (s-E)13 (Figures 4 and S10) and the visible absorption of 13 (Figure S12). These data suggest that the $(s-E)$ conformer of triplet 3-thienylcarbene 
(13) undergoes a very slow thermal reaction at $15 \mathrm{~K}$. IR experiments were performed under identical conditions to try to determine the product of this reaction, but the low concentration of triplet 3thienylcarbene (13) in the matrix, and the presence of several other photoproducts, did not permit us to quantify carbene disappearance or product growth. In general, measurements of reaction kineticswhether by EPR, UV/vis, or IR-were problematic because of a combination of low signal intensity and very slow reaction rates. Thermal reactions of reactive intermediates trapped in matrices at cryogenic temperatures are not uncommon, and these processes typically occur via a quantum mechanical tunneling mechanism ${ }^{48-50}-$ even in cases where the reaction is formally forbidden by virtue of a change in spin multiplicity. ${ }^{51,52}$ We consider the cyclization of $(s-E) 3-$ thienylcarbene (13) to 2-thiabicyclo[3.1.0]hexa-3,5-diene (12) to be a likely candidate for such a process, although we cannot exclude other possibilities (Scheme 6). The rearrangement of triplet $\mathbf{1 3}$ to singlet 12, which does not involve extensive motion of the heavy atoms, is computed to be slightly exothermic (ca. $2 \mathrm{kcal} / \mathrm{mol}$ ).

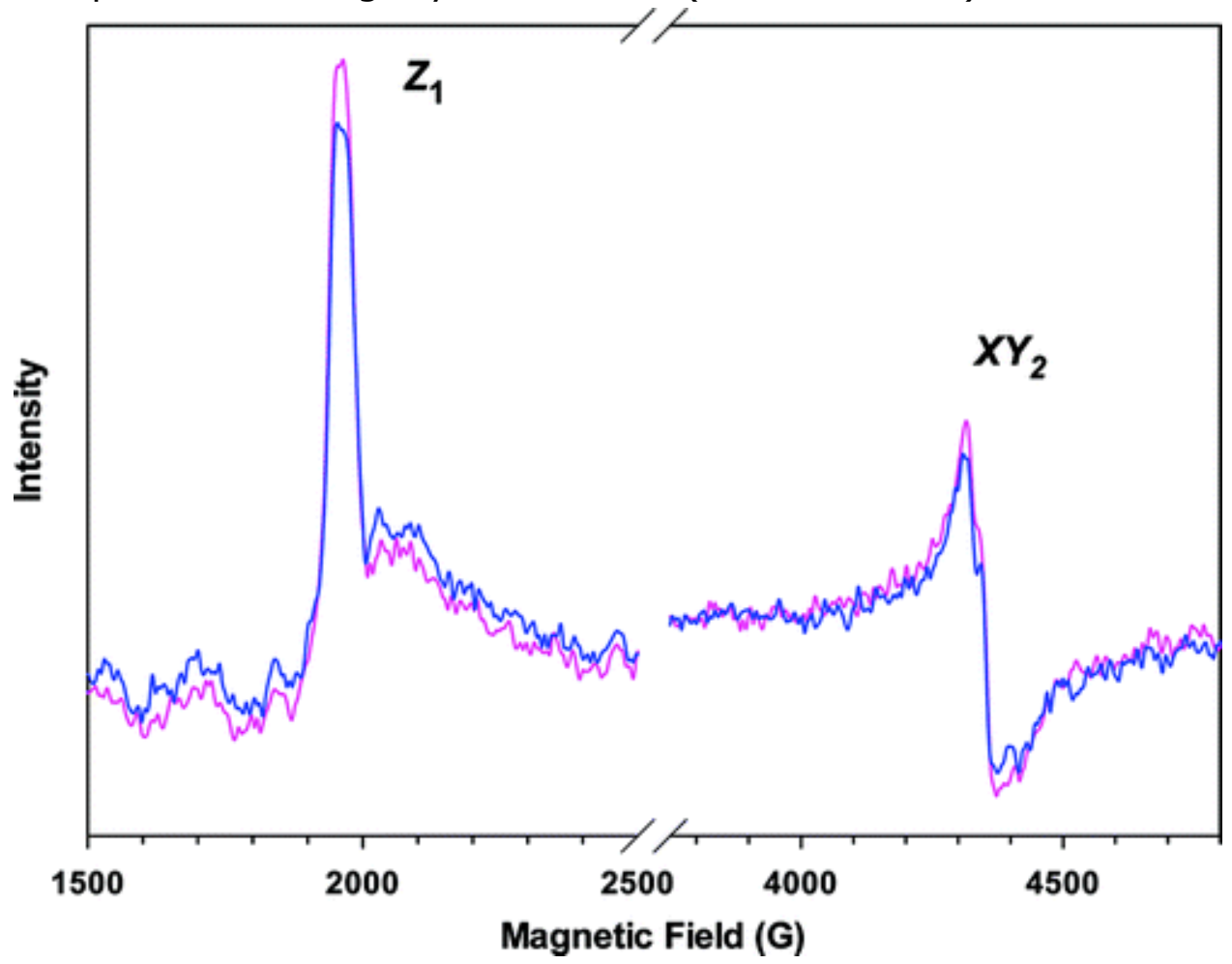

Figure 4. EPR transitions of triplet (s-E) 3-thienylcarbene (13) (Ar, $15 \mathrm{~K})$. Pink: Carbene 13 formed upon irradiation of (3-thienyl)diazomethane $(\mathbf{1})(\lambda>472 \mathrm{~nm}, 26$ h). Blue: Spectrum showing decrease in signal intensity after standing in the dark at $15 \mathrm{~K}(46 \mathrm{~h})$. 


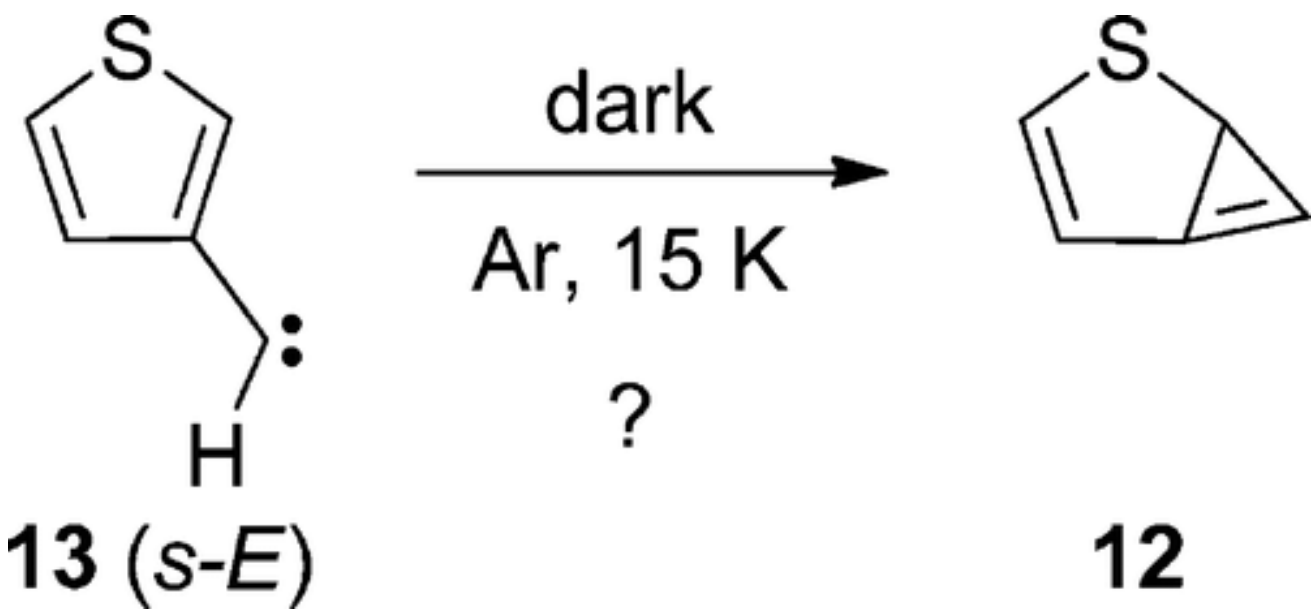

Scheme 6. Possible Tunneling Reaction of 3-Thienylcarbene (13)

\section{Photochemistry of 2-Thienyldiazomethane (2)}

Irradiation of 2-thienyldiazomethane (2), under the same conditions that led to the successful generation of triplet 3thienylcarbene (13) $(\lambda>534 \mathrm{~nm}$; Ar, $10 \mathrm{~K})$, failed to afford IR or EPR features attributable to triplet 2-thienylcarbene (11) (Scheme 7). In accord with the results of earlier studies, ${ }^{16}$ the ring-opened product, $Z$ pent-2-en-4-ynethial (6), is the only species observed by IR spectroscopy (Figure S13). Careful examination of the spectrum establishes that both $s-E$ and $s-Z$ rotamers of $\mathbf{6}$ are present. Further irradiation $(\lambda>363 \mathrm{~nm}$ ) results in cis-trans photoisomerization of $Z$ pent-2-en-4-ynethial (6) and E-pent-2-en-4-ynethial (5) (present only as the $s-E$ conformer; Figure S14). Irradiation at $\lambda>237 \mathrm{~nm}$ affords propargyl thioketene (8) (Figure S15).

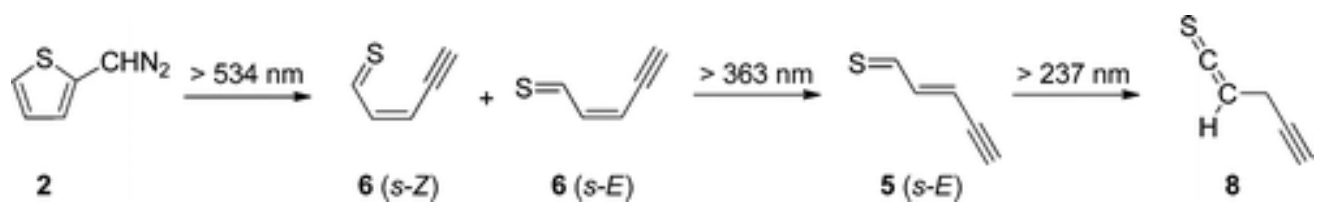

Scheme 7. Photochemistry of 2-Thienyldiazomethane (2) (Ar, $10 \mathrm{~K})$

The nature of the electronic ground state of 2-thienylcarbene (11) - singlet or triplet-remains unclear at this time. Our DFT calculations predict a triplet ground state with a small singlet-triplet gap (1-2 kcal/mol) for both conformers of 2-thienylcarbene (11) (Scheme 2). We are not overly confident in the prediction of the 
ground state multiplicity, since the two states lie so close in energy and this computational methodology typically underestimates the energy of the singlet, relative to the triplet, by $1-3 \mathrm{kcal} / \mathrm{mol} .^{35,36}$ McKee's calculations predict a singlet ground state for carbene $\mathbf{1 1}$ with a singlet-triplet gap of $4.1 \mathrm{kcal} / \mathrm{mol},{ }^{24}$ but we are not overly confident in that prediction, either. Energies reported in the earlier study were estimated by using an additivity scheme that utilized both QCISD(T) and MP2 energies. The application of MP2 methodology to carbenes, however, is problematic because of spin contamination. It is evident from the data in Table 1 of ref 24 that the QCISD(T) single-point calculation predicts a triplet ground state for $\mathbf{1 1}$, while two different MP2 single-point calculations predict a singlet ground state. ${ }^{53}$ We are inclined to discount the additivity scheme because of its reliance on MP2 data, and focus on the results afforded by CCSD (Scheme 4), QCISD $(T),{ }^{24}$ or B3LYP (Scheme 4 ), which each predict a triplet ground state with small singlet-triplet gap.

\section{Spectroscopic Data for $\mathrm{C}_{5} \mathrm{H}_{4} \mathrm{~S}$ Isomers}

3-Thienylcarbene (s-E-13): IR $\left(\mathrm{N}_{2}, 10 \mathrm{~K}\right) 744 \mathrm{~s} \mathrm{~cm}^{-1}$; UV/vis $(\mathrm{Ar}, 10 \mathrm{~K}) \lambda_{\max } 441,449,457,467 \mathrm{~nm}$; $\operatorname{EPR}(\mathrm{Ar}, 15 \mathrm{~K}),|D / h c|=$ $0.508 \mathrm{~cm}^{-1},|E / h c|=0.0554 \mathrm{~cm}^{-1}, Z_{1}=1954.7 \mathrm{G}, X_{2}=4250.0 \mathrm{G}, Y_{2}$ $=6550.4 \mathrm{G}, Z_{2}=8823.2 \mathrm{G}$, microwave frequency $=9.491 \mathrm{GHz}$. 3Thienylcarbene (s-Z-13): IR $\left(\mathrm{N}_{2}, 10 \mathrm{~K}\right) 744 \mathrm{~s} \mathrm{~cm}^{-1}$; UV/vis (Ar, $\left.10 \mathrm{~K}\right)$ $\lambda_{\max } 441,449,457,467 \mathrm{~nm}$; EPR $(\operatorname{Ar}, 15 \mathrm{~K}),|D / h c|=0.579 \mathrm{~cm}^{-1}$, $|E / h c|=0.0315 \mathrm{~cm}^{-1}, Z_{1}=2770.0 \mathrm{G}, X_{2}=5000.0 \mathrm{G}, Y_{2}=6337.0 \mathrm{G}$, $Z_{2}=9600.0 \mathrm{G}$, microwave frequency $=9.491 \mathrm{GHz}$. (s-E)-E-Pent-2-en4-ynethial (5): IR (Ar, 10 K) 3319 s, 1575 s, 1362 w, 1255 m, 1163 m, 1159 m, 976 w, 971 w, 962 m, 776 w, 694 w, 643 w, 640 w, 631 w cm ${ }^{-1}$. (s-E)-Z-Pent-2-en-4-ynethial (6): IR (Ar, $10 \mathrm{~K}$ ) $3317 \mathrm{~s}, 2109$ w, 1560 s, 1404 s, 1258 w, 1218 m, 1130 s, 1031 s, 862 w, 854 w, 777 s, 700 m, 643 s, 629 m, 465 w cm$^{-1}$. (s-Z)-Z-Pent-2-en-4ynethial (6): IR (Ar, 10 K) 3327 s, 2109 w, 1554 m, 1410 m, 1364 w, 1257 m, 1128 m, 1134 m, 944 w, 858 w, 638 s, 629 m, 465 w cm ${ }^{-1}$. Propargyl thioketene (8): IR ( $\left.\mathrm{N}_{2}, 10 \mathrm{~K}\right) 3316 \mathrm{~m}, 1779 \mathrm{~s}, 1318 \mathrm{w}, 1253$

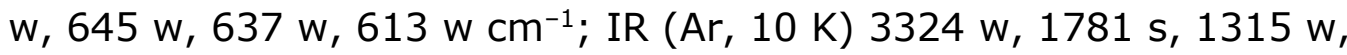
$1245 \mathrm{w} \mathrm{cm}^{-1}$. (s-Z)-a-Thial-methylenecyclopropene (9): IR ( $\mathrm{N}_{2}, 10 \mathrm{~K}$ ) 3141 w, 1718 s, 1498 w, 1474 m, 1367 m, 1358 m, 1189 w, 1169 m, 1009 w, 775 m, 696 w, 646 w, 629 w cm-1. (s-E)-a-Thial- 
methylenecyclopropene (9): IR ( $\left.\mathrm{N}_{2}, 10 \mathrm{~K}\right) 3143 \mathrm{w}, 1719 \mathrm{~s}, 1714 \mathrm{~m}$, 1496 s, 1480 m, 1412 w, 1362 w, 1353 w, 1190 m, 1164 m, 1104 w, 1007 w, 912 w, 908 w, 843 w, 834 w, 718 w cm cm. $^{-1}$.

\section{Photochemistry of 3-Furyldiazomethane (3)}

Irradiation of 3-furyldiazomethane (3), under the same conditions that led to the successful generation of triplet 3thienylcarbene (13) from 3-thienyldiazomethane (1) $(\lambda>571 \mathrm{~nm}$ or $>$ $534 \mathrm{~nm}$; Ar, $10 \mathrm{~K})$, failed to afford IR or EPR features attributable to triplet 3-furylcarbene (22) (Scheme 8). Long-wavelength irradiation ( $\lambda$ $>571 \mathrm{~nm}$ ) of $\mathbf{3}$ yields a mixture of (a-formyl)methylenecyclopropene (s-Z- and $s-E-19)$ and an unidentified species (U) exhibiting an IR band in the acetylenic $\mathrm{C}-\mathrm{H}$ stretching region (3429 m, $1636 \mathrm{~m}, 1476$ $\mathrm{m} \mathrm{cm}^{-1}$, Figure S16). Irradiation at $\lambda>399 \mathrm{~nm}$ drives (s-Z)-19 away, while (s-E)-19 and $\mathbf{U}$ continue to grow (Figure S17). Subsequent irradiation $(\lambda>330 \mathrm{~nm})$ causes 19 to decrease in intensity and a mixture of E-pent-2-en-4-ynal (16) and Z-pent-2-en-4-ynal (17) to appear. As in the case of the sulfur analogues, the pent-2-en-4-ynals (16 and 17) are present in the $s-E$ conformation (Figure S18). The IR assignments for 16, 17, and 19 are in good agreement with those reported previously. ${ }^{17}$
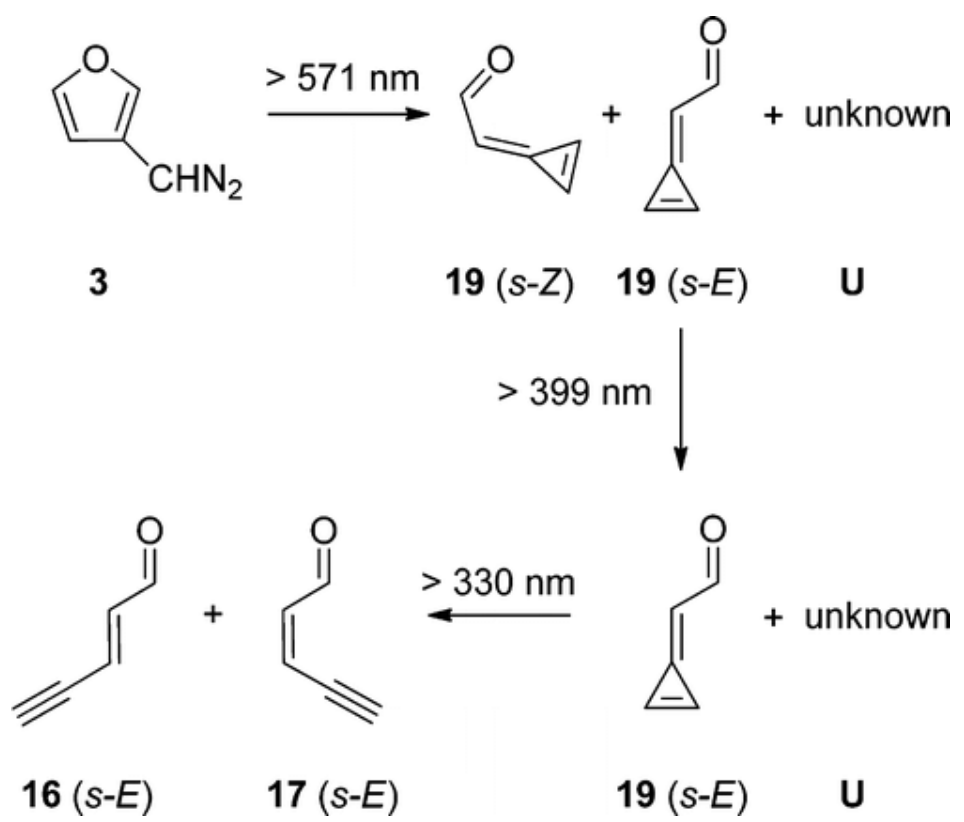

Scheme 8. Photochemistry of 3-Furyldiazomethane (3) ( $\mathrm{Ar}, 10 \mathrm{~K})$

Journal of the American Chemical Society, Vol 134, No. 14 (March 2012): pg. 6443-6454. DOI. This article is (C) American Chemical Society and permission has been granted for this version to appear in e-Publications@Marquette. American Chemical Society does not grant permission for this article to be further copied/distributed or hosted elsewhere without the express permission from American Chemical Society. 
The photochemical appearance and disappearance of compound $\mathbf{U}$ is reproducible across multiple experiments, yet the identity of this species eludes us. We initially suspected propargyl ketene (18)-the oxygen analogue of propargyl thioketene (8) that was observed in the photochemistry of the related sulfur-containing system. The observed IR absorptions of $\mathbf{U}$, however, are inconsistent with the IR spectrum computed for ketene 18. (The apparent absence of ketene or carbonyl stretching vibrations in the spectrum of $\mathbf{U}$ is telling.) We considered several other $\mathrm{C}_{5} \mathrm{H}_{4} \mathrm{O}$ isomers that contain a terminal alkyne moiety (Scheme S2), but none of the computed IR spectra shows a good correlation with the experimentally observed bands of $\mathbf{U}$. We also considered the possibility of a photofragmentation reaction, but the observed IR absorption at $3429 \mathrm{~cm}^{-1}$ does not correspond to that of either acetylene ${ }^{54}$ or diacetylene.

\section{Photochemistry of 2-Furyldiazomethane (4)}

Under gentler conditions than those that led to the successful generation of triplet 3-thienylcarbene (13) $(\lambda>571 \mathrm{~nm} ; \mathrm{Ar}, 10 \mathrm{~K})$, irradiation of (2-furyl)diazomethane (4) $(\lambda>613 \mathrm{~nm}$; $\mathrm{Ar}, 10 \mathrm{~K}$ ) failed to afford IR or EPR features attributable to triplet 2-furylcarbene (22) (Scheme 9). In accord with the results of earlier studies, ${ }^{17}$ irradiation of diazo compound 4 ( $\lambda>613 \mathrm{~nm}$; Ar, $10 \mathrm{~K}$ ) causes fragmentation of the furan ring, yielding Z-pent-2-en-4-ynal (17) (Figure S19).

Subsequent irradiation at $\lambda>444 \mathrm{~nm}$ gives rise to $E$-pent-2-en-4-ynal (16) (Scheme 9, Figure S20).

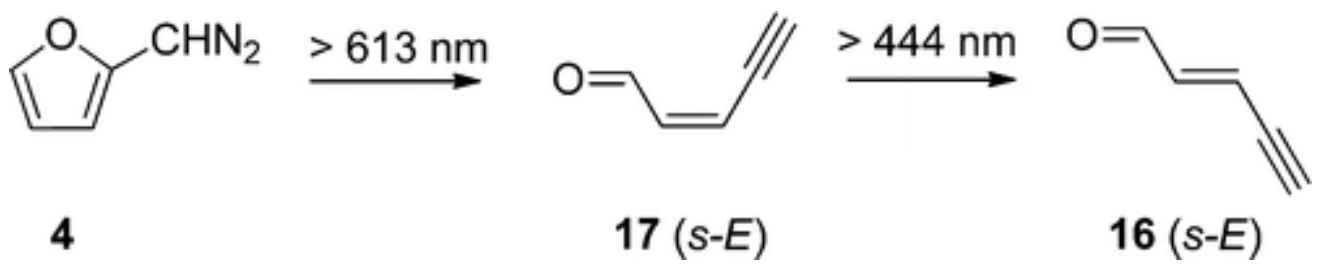

Scheme 9. Photochemistry of 2-Furyldiazomethane (4) (Ar, $10 \mathrm{~K})$

\section{Spectroscopic Data for $\mathrm{C}_{5} \mathrm{H}_{4} \mathrm{O}$ Isomers}

(s-E)-E-Pent-2-en-4-ynal (16): IR (Ar, $10 \mathrm{~K}) 3313 \mathrm{~m}, 1710 \mathrm{~s}$, 1594 m, 1264 w, 1124 s, 963 m, 716 w, 641 m, 583 w cm-1. (s-E)-ZPent-2-en-4-ynal (17): IR (Ar, 10 K) 3324 m, 2845 w, 2826 w, 2743 
w, 1699 s, 1582 m, 1266 w, 1096 w, 909 m, 643 w cm-1. (s-Z)-(aFormyl)methylenecyclopropene (19): IR ( $\mathrm{Ar}, 10 \mathrm{~K}) 1749 \mathrm{~s}, 1647 \mathrm{~s}$, 1494 m, 1344 w, 1114 w, 1080 w, 729 w, 705 m, $602 \mathrm{~m} \mathrm{~cm}^{-1}$. (s-E)(a-Formyl)methylenecyclopropene (19): IR (Ar, 10 K) 1743 w, $1690 \mathrm{~s}$, $1665 \mathrm{w}, 1511 \mathrm{~m}, 1146 \mathrm{w}, 1016 \mathrm{w}, 799 \mathrm{w} \mathrm{cm}^{-1}$. Unknown (U): IR (Ar, 10 K) $3429 \mathrm{~m}, 1636 \mathrm{~m}, 1476 \mathrm{~m} \mathrm{~cm}^{-1}$.

\section{Discussion}

\section{EPR Spectrum and Electronic Structure of Triplet 3- Thienylcarbene (13)}

The triplet EPR spectrum obtained upon irradiation of 3thienyldiazomethane (1) (Figure 1) exhibits several unusual features, with respect to the spectra of triplet arylcarbenes. ${ }^{39,55-57}$ Conformational isomerism, a heavy atom effect of sulfur, and site effects in the matrix may all be manifest in the spectrum, and a proper interpretation is not readily apparent upon cursory inspection. The assignment of the individual EPR transitions to major and minor conformational isomers derives from the differential rate of appearance as a function of photolysis wavelength $(\lambda>571$ vs $\lambda>$ 472 nm; Figure 1 and Figure S8), as well as comparison with EPR spectra of other 2- and 3-thienylcarbene derivatives obtained in subsequent investigations. ${ }^{58,59}$ The zero-field splitting parameters of the major and minor isomers were calculated in the usual way, using the best fit of the EPR transitions with the spin Hamiltonian under the assumption that $g_{x}=g_{y}=g_{z}=g_{\mathrm{e}} .{ }^{60}$ The striking result is the large difference in magnitude of the $D$ values between the major ( $D=0.508$ $\left.\mathrm{cm}^{-1}\right)$ and minor $\left(D=0.579 \mathrm{~cm}^{-1}\right)$ isomers observed in the triplet EPR spectrum.

\section{Simulation}

Simulation of the triplet EPR spectrum, using the program XSophe (Bruker), was accomplished by manually varying values of $D$, $E$, and $g$ to give an optimal fit. The experimental and simulated spectra exhibit excellent agreement (Figure 5 ). The best fit was obtained with $g=2.0$ and the zero-field parameters $D$ and $E$ given in Table 2 . In the experimental spectrum, the major isomer exhibits subtle features in

Journal of the American Chemical Society, Vol 134, No. 14 (March 2012): pg. 6443-6454. DOI. This article is (C) American Chemical Society and permission has been granted for this version to appear in e-Publications@Marquette. American Chemical Society does not grant permission for this article to be further copied/distributed or hosted elsewhere without the express permission from American Chemical Society. 
the $X_{2}$ and $Y_{2}$ transitions, which we attribute to inequivalent sites in the argon matrix. These features are well-reproduced, in the simulated spectrum, by two species ( $A$ and $A^{\prime}$ ) that differ only slightly in terms of $E$ value (Table 2). Although the $g=2$ signal in the experimental spectrum appears to be intense, its contribution in terms of percent of spins is negligible $(0.3 \%)$, as established by the simulation. The quality of the simulated spectrum, and the excellent agreement of the zero-field parameters determined from the experimental spectrum and from the simulated spectra give confidence in the correctness of the analysis.

Table 2. Zero-Field Splitting Parameters (in $\mathrm{cm}^{-1}$ ) of Triplet 3-Thienylcarbene (13)

\section{experimental XSophe simulation}

conformer $|D / h c||E / h c||D / h c||E / h c| \%$ spins

$\begin{array}{lrrrr}\text { A } & 0.508 & 0.0554 & 0.505 & 0.0545456 \\ \text { A }^{\prime} & & 0.505 & 0.0570728 \\ \text { B } & 0.579 & 0.0315 & 0.575 & 0.0312816 \\ g=2 & & & & 0.3\end{array}$

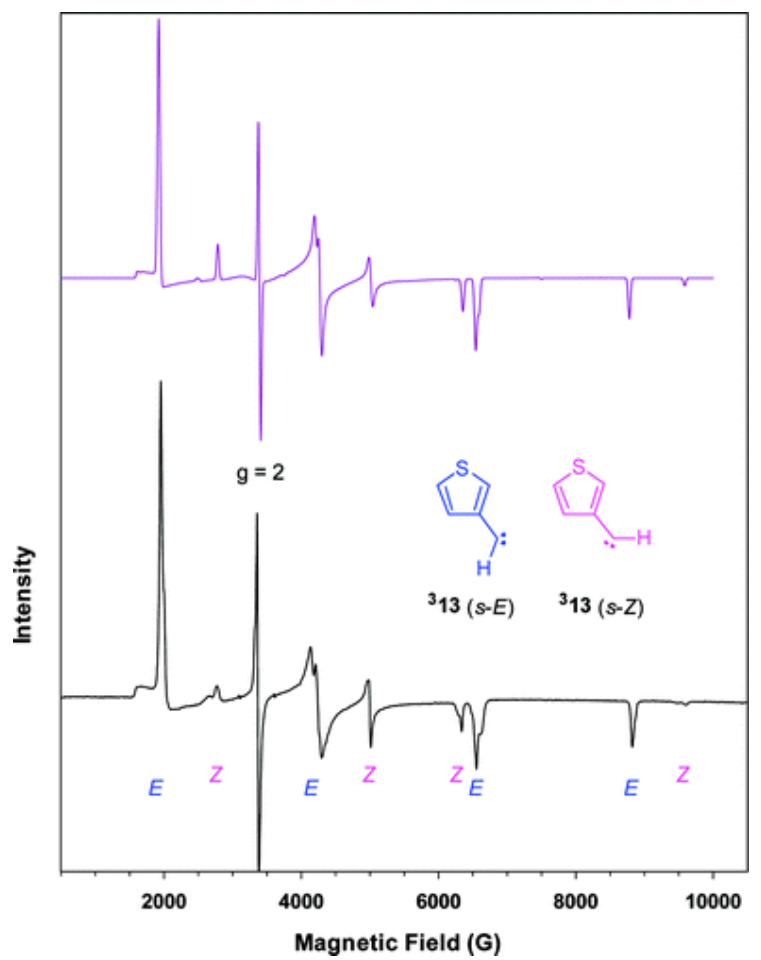

Figure 5. Bottom: EPR spectrum of triplet $(s-E)$ and (s-Z)-3-thienylcarbene (13), obtained upon irradiation ( $\lambda>472 \mathrm{~nm}, 22 \mathrm{~h}$ ) of 3-thienyldiazomethane (1) (Ar, $15 \mathrm{~K})$. Top: Simulated spectrum of triplet 3-thienylcarbene (13) (see text).

Journal of the American Chemical Society, Vol 134, No. 14 (March 2012): pg. 6443-6454. DOI. This article is (C) American Chemical Society and permission has been granted for this version to appear in e-Publications@Marquette. American Chemical Society does not grant permission for this article to be further copied/distributed or hosted elsewhere without the express permission from American Chemical Society. 
That the EPR spectrum of triplet 3-thienylcarbene (13) could be interpreted and simulated by using $g=2.0$ was not obvious to us, at the outset, because of the possible influence of a heavy-atom effect by sulfur. Sulfur-containing radicals have been widely studied in biological systems. ${ }^{61}$ In cases where an unpaired electron is localized on sulfur, $g$ values range from 1.96 to $2.073 .{ }^{62}$ In the case of carbene $\mathbf{1 3}$, the fact that little spin density resides at sulfur (see below), and that the nature of the EPR spectrum is much more sensitive to the values of $D$ and $E$ than to the value of $g$, suggest that any manifestation of spinorbit coupling on $g$, through the heavy-atom effect of sulfur, is minimal.

\section{Spectroscopic Assignments}

The preceding analysis provides the zero-field splitting parameters for the major and minor species observed in the matrix, but it does not establish the spectroscopic assignments. In making the assignments, we consider several interpretations of the EPR spectrum (Figure 4). In the first, which is the assignment that we ultimately favor, we hypothesize that the transitions for the major and minor isomers arise from $s-E / s-Z$ conformational isomerism of triplet 3thienylcarbene (13). (In other words, the EPR spectra of the conformational isomers are quite different.) In this scenario, the spectral doubling of the $X_{2}$ and $Y_{2}$ transitions is attributed to matrix site splitting.

In the second interpretation of the EPR spectrum, we hypothesize that the transitions for the major isomer-for which the $X_{2}$ and $Y_{2}$ transitions exhibit features of spectral doubling-arise from conformational isomers of triplet 3-thienylcarbene (13). (In other words, the EPR spectra of the conformational isomers are quite similar.) We hypothesize that the transitions for the minor isomerwhich are quite different-arise from a different triplet species. In our mind, a plausible candidate is 4-thia-2,5-cyclohexadienylidene (10) (Scheme 10), which could be readily envisioned to form upon photochemical or hot molecule rearrangement of 3-thienylcarbene (13) and bicyclic compound 12. DFT calculations by McKee et al. ${ }^{24}$ and by us (Scheme 2), however, predict a singlet ground state for 4-thia- 
2,5-cyclohexadienylidene (10). We therefore reject the assignment of $\mathbf{1 0}$ as a carrier of a triplet EPR signal.<smiles>c1ccsc1</smiles>

7

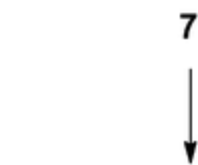<smiles>[CH]c1cccs1</smiles><smiles>[Tl]c1cccs1</smiles><smiles>[TlH]c1ccsc1</smiles><smiles>Cc1ccsc1</smiles>

$13(s-E) \quad 13(s-Z)$

.

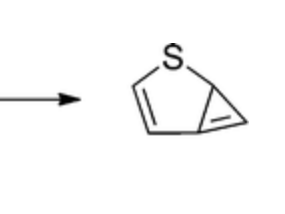

12

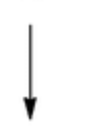<smiles>c1ccccc1</smiles>

10

$\begin{array}{lc}11(s-E) & 11(s-Z) \\ \text { Scheme 10. Plausible Carbene Rearrangements }\end{array}$

In the third interpretation of the EPR spectrum, we hypothesize that the transitions for the major and minor isomers arise from the presence of a mixture of triplet 2-thienylcarbene (11) and 3thienylcarbene (13). (In this scenario, the doubling of spectral transitions might arise through either $s-E / s-Z$ conformational isomerism or multiple matrix sites.) That triplet 2-thienylcarbene (11) cannot be generated by direct irradiation of (2-thienyl)diazomethane (2) does not exclude the possibility that triplet $\mathbf{1 1}$ might be formed and observable under different reaction conditions (e.g., photochemical or hot molecule rearrangement of 3-thienylcarbene (13) or 4-thiacyclohexa-1,2,5-triene (7); Scheme 10). Although this scenario seems improbable-given the very low barrier for ringopening of singlet 2-thienylcarbene (11)-we cannot rigorously exclude it.

\section{Conformational Isomerism}

Here, we follow the analysis of Roth and co-workers assigning geometric isomers for triplet arylcarbenes. ${ }^{55-57}$ If the conformational isomers of a triplet carbene experience different dipolar coupling between the unpaired electrons, the conformers will exhibit different $D$ values. Differences in dipolar coupling may arise as a consequence of

Journal of the American Chemical Society, Vol 134, No. 14 (March 2012): pg. 6443-6454. DOI. This article is (c) American Chemical Society and permission has been granted for this version to appear in e-Publications@Marquette. American Chemical Society does not grant permission for this article to be further copied/distributed or hosted elsewhere without the express permission from American Chemical Society. 
differences in spin density at the $\beta$-positions of a triplet carbene in which one unpaired electron is delocalized across a n-electron system. Thus, we computed natural spin densities for both triplet 3thienylcarbene (13) and 3-furylcarbene (23) (Table 3). The finding of a large difference in spin density at the $\beta$-positions of the carbene (C2 $=+0.42, \mathrm{C} 4=+0.13)$ is consistent with a large difference in the $D$ values of the conformational isomers of 3-thienylcarbene (13) 0.508 $\mathrm{cm}^{-1}$ vs $0.579 \mathrm{~cm}^{-1}$ ). Empirical correlations establish that the larger $D$ value arises when the sp orbital of a triplet carbene is oriented anti with respect to the $\beta$-position bearing the larger spin density. ${ }^{55-57}$ Since $\mathrm{C} 2$ is the $\beta$-position bearing higher spin density in triplet 3thienylcarbene (13), the $s-Z$ conformer of $\mathbf{1 3}$ is assigned as the isomer with the larger $D$ value (minor isomer in Figure 5), and the $s-E$ conformer of $\mathbf{1 3}$ is assigned as the isomer with the smaller $D$ value (major isomer in Figure 5). It is interesting to note that the difference in $D$ values between the two conformers of 3-thienylcarbene ( $\Delta D=$ $0.071 \mathrm{~cm}^{-1}$ ) is substantially larger than the difference observed for conformers of most arylcarbenes $\left(\Delta D \approx 0.02-0.03 \mathrm{~cm}^{-1}\right)$, vinylcarbenes $\left(\Delta D \approx 0.05 \mathrm{~cm}^{-1}\right)$, and a-carbonylcarbenes $(\Delta D \approx 0.05$ $\left.\mathrm{cm}^{-1}\right) .{ }^{55-57}$ The value rivals that reported for the conformers of benzoyl phenyl carbene $\left(\Delta D=0.08 \mathrm{~cm}^{-1}\right)$.

Table 3. Natural Spin Densities and Zero-Field Splitting Parameters for Triplet 3-Thienylcarbene (13) and Triplet 3-Furylcarbene (23)
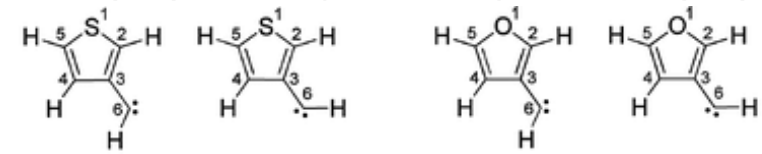

\begin{tabular}{|c|c|c|c|c|}
\hline \multirow[b]{2}{*}{ Atom } & \multicolumn{2}{|c|}{ 3-thienylcarbene (13) } & \multicolumn{2}{|c|}{ 3-furylcarbene (23) } \\
\hline & $(s-E)-13$ & $(s-Z)-13$ & $(s-E)-23$ & $(s-Z)-23$ \\
\hline 1 & +0.071 & +0.087 & +0.043 & +0.052 \\
\hline 2 & +0.415 & +0.431 & +0.416 & +0.435 \\
\hline 3 & -0.180 & -0.182 & -0.179 & -0.180 \\
\hline 4 & +0.128 & +0.105 & +0.121 & +0.097 \\
\hline 5 & -0.076 & -0.078 & -0.060 & -0.063 \\
\hline \multirow[t]{2}{*}{6} & +1.67 & +1.67 & +1.69 & +1.68 \\
\hline & \multicolumn{2}{|c|}{ experimental } & \multicolumn{2}{|c|}{ computed } \\
\hline$|D / h c| \mathrm{cm}^{-1}$ & 0.508 & 0.579 & 0.506 & 0.531 \\
\hline$|E / h c| \mathrm{cm}^{-1}$ & 0.0554 & 0.0315 & 0.0323 & 0.0297 \\
\hline
\end{tabular}

Table aNBO spin densities at B3LYP/6-31G*; zero-field splitting parameters at B3LYP/EPRIII.

Journal of the American Chemical Society, Vol 134, No. 14 (March 2012): pg. 6443-6454. DOI. This article is (C) American Chemical Society and permission has been granted for this version to appear in e-Publications@Marquette. American Chemical Society does not grant permission for this article to be further copied/distributed or hosted elsewhere without the express permission from American Chemical Society. 
In an effort to obtain independent evidence bearing on the assignment of the conformational isomers of triplet 3-thienylcarbene (13), we sought to utilize newly developing methods for the firstprinciples calculation of zero-field splitting parameters. Neese's ORCA program shows considerable promise for the analysis of a variety of high-spin organic reactive intermediates. ${ }^{63-66}$ Unfortunately, we find that the ORCA calculations for the zero-field splitting parameters of triplet 3-thienylcarbene (13) are not robust. The computed values of $D$ and $E$ are much too sensitive to the basis set and level of theory. These problems are not manifest in calculations of the corresponding 3-furylcarbene (23) and therefore appear to be related to the presence of the second-row atom (sulfur). For species composed only of first-row elements, the spin-spin interaction term makes the dominant (sole) contribution to $D$. These systems appear to be wellhandled by ORCA. For species that include heavier elements, Neese has shown that the spin-orbit interaction term makes the dominant contribution to $D .64$

Comparison of 3-thienylcarbene (13) and 3-furylcarbene (23) is instructive. The computed zero-field splitting parameters of 3furylcarbene (23) exhibit the expected effects of conformational isomerism (Table 3 ), and the prediction that the $(s-Z)$ conformer displays the larger $D$ value is consistent with the qualitative expectations described in the preceding section. The difference in $D$ values between the two conformers of 3-furylcarbene (23) $(\Delta D=$ $0.025 \mathrm{~cm}^{-1}$ ), however, is significantly smaller than that of 3thienylcarbene $(\mathbf{1 3})\left(\Delta D=0.071 \mathrm{~cm}^{-1}\right)$. While the very good agreement between the $D$ values for the $(s-E)$ conformers of these carbenes is undoubtedly fortuitous $\left(0.508 \mathrm{~cm}^{-1}\right.$ observed for $13 ; 0.506$ $\mathrm{cm}^{-1}$ computed for $\mathbf{2 3}$ ), it serves to focus attention on the fact the experimental and computed $D$ values for the $(s-Z)$ conformers differ substantially $\left(0.579 \mathrm{~cm}^{-1}\right.$ observed for $13 ; 0.531 \mathrm{~cm}^{-1}$ computed for 23). Although the computed spin densities in both systems are quite similar (Table 2), there appears to be an interaction in the $(s-Z)$ conformer of triplet 3-thienylcarbene (13) that renders it uniquely different, in terms of its zero-field splitting parameter $D$.

We employed NBO calculations to investigate the possible electronic interactions between the sulfur heteroatom and the triplet 
carbene center in 3-thienylcarbene (13). Perhaps the most important conclusion from these studies is the absence of a readily identifiable, dominant interaction between these centers. The analysis does reveal a weak interaction between the filled sp orbital at the carbene carbon and the empty antibonding $\sigma$ orbital of the C2-S1 bond in the $s-Z$ isomer (Figure 6). This interaction was absent in the $s-E$ isomer. The energy of this interaction is not large $(0.37 \mathrm{kcal} / \mathrm{mol})$, but it does reveal a subtle distinction in the electronic structure of the conformational isomers.
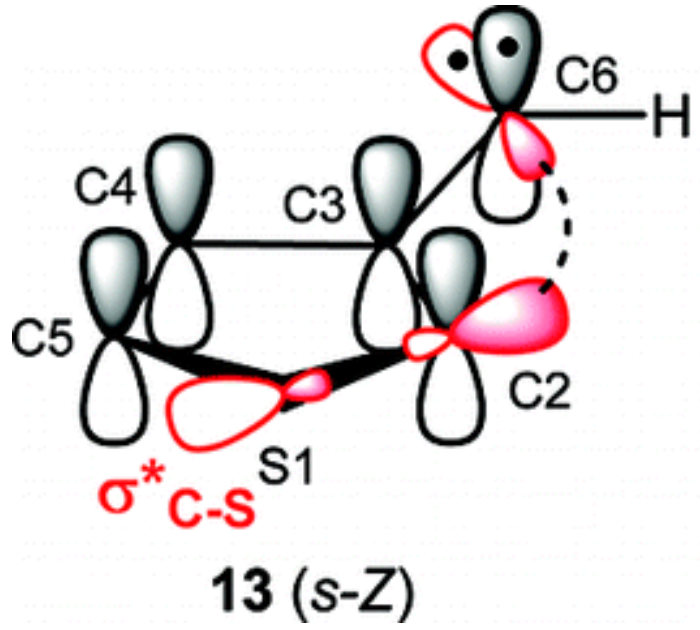

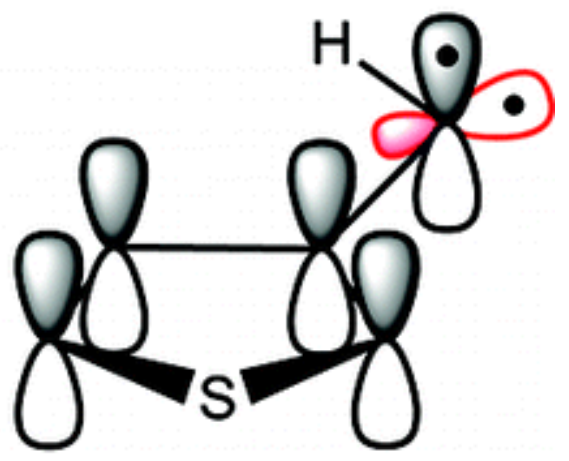

$13(s-E)$

Figure 6. Natural Bond Orbital analysis of triplet 3-thienylcarbene (13).

In summary, our analysis of conformational isomerism in triplet 3-thienylcarbene (13) is commensurate with a conventional interpretation, in which differences in spin density at the nonequivalent ortho positions give rise to differences in dipolar spin-spin coupling. NBO analyses provide a tenuous hint concerning differential electronic interactions between sulfur and the carbene moiety in the $s-E$ and $s-Z$ conformers of triplet 13. It should be noted, however, that nothing in the analysis rigorously requires the assignment of conformers to be correct. The structural assignment is based upon model systems that do not contain a heavy atom. ${ }^{57}$ Literature precedent, although sparse, suggests that the spin-orbit contribution in a system that contains a heavy atom will be dominant. ${ }^{64}$ It is conceivable that a significant spin-orbit contribution could reverse the predictions of which conformer has the larger or smaller $D$ value, thereby reversing the 
NOT THE PUBLISHED VERSION; this is the author's final, peer-reviewed manuscript. The published version may be accessed by following the link in the citation at the bottom of the page.

assignments of $s-E$ and $s-Z$ conformers of triplet 3-thienylcarbene (13).

\section{Absence of the Other Carbenes}

The inability to generate and characterize triplet 3-furylcarbene (23) was the biggest disappointment for us in the current investigation. The electronic absorption spectrum of 3furyldiazomethane (3) is quite similar to the corresponding sulfur analogue (1), and we did not anticipate a significant difference in the photochemistry of these diazo compounds. For both oxygen- and sulfur-containing carbenes (23 and 13), DFT calculations predict triplet ground states for both $s-E$ and $s-Z$ conformers, with small singlet-triplet energy gaps (ca. 2-5 kcal/mol) (Schemes 2-4). The computed singlet-triplet gaps of the 3-furylcarbenes (23) are slightly smaller than those of the 3-thienylcarbenes (13)-the species that are spectroscopically observed. One conclusion to be gleaned from the computational data shown in Schemes 2 and 3 is that the methylenecyclopropene derivatives, which are formed as the major products during the initial photolysis, lie significantly lower in energy than the singlet carbenes for the oxygen series (ca. $24 \mathrm{kcal} / \mathrm{mol}$ lower), compared to the sulfur series (ca. $14 \mathrm{kcal} / \mathrm{mol}$ lower). This situation is consistent with a scenario in which a vibrationally hot 3furylcarbene (23) would be more prone to suffer rearrangement to methylenecyclopropene (19) than the corresponding 3-thienylcarbene (13)-relative to undergoing vibrational cooling by the matrix.

The inability to generate and characterize 2-thienylcarbene (11) or 2-furylcarbene (22) is less surprising. DFT calculations, by us and by others, ${ }^{30,31}$ predict a singlet ground state for both conformers of 2furylcarbene (22). The recent analysis by Herges and Haley reveals a substantial thermodynamic stabilization of heteroaryl carbenes. ${ }^{28}$ Ringopening of 2-thienylcarbene (11) or 2-furylcarbene (22) to the corresponding pentenynal is exothermic, relative to the singlet carbenes, by $20 \mathrm{kcal} / \mathrm{mol}$ in the sulfur case and $30 \mathrm{kcal} / \mathrm{mol}$ in the oxygen case. The computed barriers for ring-opening of syn- and anti2-furylcarbene (22) are very low (2-4 kcal/mol). ${ }^{30,31}$ Herges $^{29}$ described the reaction as a coarctate transformation, while Birney ${ }^{31}$ interpreted it as a pseudopericyclic process. Independent of the 
classification, in terms of orbital symmetry, the reaction is one that may be envisioned to occur via a tunneling mechanism (at least at cryogenic temperature). Our experiments, of course, do not establish that either 2-thienylcarbene (11) or 2-furylcarbene (22) is directly involved in the photochemistry of the corresponding diazo compounds. The literature contains many examples in which reactions occur in an excited state of a diazo compound, circumventing a carbene intermediate altogether. ${ }^{45,46}$

\section{Conclusions}

Triplet 3-thienylcarbene (13) has been generated upon irradiation of 3-thienyldiazomethane (1) $(\lambda>534 \mathrm{~nm})$ and characterized by IR, UV/Vis, and EPR spectroscopy. The $s-E$ and $s-Z$ conformers of the triplet carbene exhibit substantially different zerofield splitting parameters ( $D=0.508$ and $0.579 \mathrm{~cm}^{-1}$, respectively), which arise as a consequence of a large difference in spin density at the two ortho positions in the thiophene ring. Despite finding experimental conditions for the successful generation of triplet 3thienylcarbene, the conditions were not transferable for generating triplet 2-thienylcarbene (11) or the isomeric 2- or 3-furylcarbenes $(22,23)$.

\section{Methods Section}

\section{General}

${ }^{1} \mathrm{H}$ NMR spectra (300 MHz) were obtained in $\mathrm{Me}_{2} \mathrm{SO}-d_{6}$; chemical shifts $(\delta)$ are reported as ppm downfield from internal SiMe 4 . Mass spectra and exact mass measurement (EMM) were obtained by using electrospray ionization (ESI). Thiophene-3-carboxaldehyde, thiophene2-carboxaldehyde, furan-3-carboxaldehyde, and furan-2carboxaldehyde were purchased from commercial sources and purified by vacuum distillation. The matrix isolation apparatus and technique have been described previously, ${ }^{67,68}$ and additional details are provided as Supporting Information. 
NOT THE PUBLISHED VERSION; this is the author's final, peer-reviewed manuscript. The published version may be accessed by following the link in the citation at the bottom of the page.

\section{Computational Methods}

Optimized geometries, energies, and infrared intensities were obtained at the B3LYP/6-31G* level of theory, using the Gaussian software package. ${ }^{69}$ The nature of stationary points was confirmed by calculation of the harmonic vibrational frequencies, which also provided zero-point vibrational energy (ZPVE) corrections. Vibrational frequencies were not scaled. Geometries, harmonic vibrational frequencies, and singlet-triplet energy gaps for 2- and 3thienylcarbene (11 and 13) were also computed by using coupledcluster methodology, CCSD, ${ }^{70}$ which includes single and double excitations. The correlation-consistent cc-pVTZ basis set was used. ${ }^{71-73}$ All CCSD calculations were done in the frozen-core approximation with the CFOUR program system. ${ }^{74}$ Natural bond orbital (NBO) calculations were performed at the B3LYP/6-31G* level of theory using the NBO program. ${ }^{75}$ Electronic absorption spectra were computed at the B3LYP/6-31G* geometries, using time-dependent density functional theory methods (M06 and CAM-B3LYP) and the aug-cc-pVTZ basis set, as implemented in Gaussian09. ${ }^{69}$ First-principles calculations of zerofield splitting parameters $D$ and $E$ were performed at the B3LYP/631G* geometries, using the B3LYP functional and the EPRIII basis set, as implemented in the ORCA program. ${ }^{76}$ Simulations of EPR spectra of randomly oriented triplets were performed with use of the XSophe program, ${ }^{77}$ as supplied by Bruker Instruments. The matrix diagonalization method was utilized (with 1600 partitions and 8 segments).

\section{Preparation of Tosylhydrazones}

The tosylhydrazone precursors to compounds $\mathbf{1}, \mathbf{2}, \mathbf{3}$, and $\mathbf{4}$ were synthesized by using a modified method given by Katritzky. ${ }^{78} p$ Toluenesulfonhydrazide $(4.65 \mathrm{~g}, 25 \mathrm{mmol})$ was added to a solution of the corresponding aldehyde $(25 \mathrm{mmol})$ in $30 \mathrm{~mL}$ of methanol and refluxed for $12 \mathrm{~h}$. The solution was diluted with water $(50 \mathrm{~mL})$ and the precipitate was collected by suction filtration. The crude product was recrystallized from methanol.

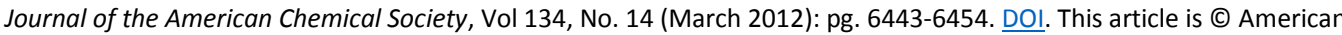
Chemical Society and permission has been granted for this version to appear in e-Publications@Marquette. American Chemical Society does not grant permission for this article to be further copied/distributed or hosted elsewhere without the express permission from American Chemical Society. 


\section{Thiophene-3-carboxaldehyde Tosylhydrazone}

White crystals, yield $70 \%$; mp $155-157{ }^{\circ} \mathrm{C}$ (lit. ${ }^{22} \mathrm{mp} 157.5-$ $\left.159^{\circ} \mathrm{C}\right) ;{ }^{1} \mathrm{H}$ NMR $\left(\mathrm{Me}_{2} \mathrm{SO}-d_{6}\right) \delta 2.35(\mathrm{~s}, 3 \mathrm{H}), 7.27(\mathrm{~d}, J=4.6 \mathrm{~Hz}, 1 \mathrm{H})$, $7.39(\mathrm{~d}, J=8.5 \mathrm{~Hz}, 2 \mathrm{H}), 7.56(\mathrm{dd}, J=4.9,2.8 \mathrm{~Hz}, 1 \mathrm{H}), 7.75(\mathrm{~d}, J=$ $8.2 \mathrm{~Hz}, 2 \mathrm{H}), 7.80(\mathrm{~d}, J=1.9 \mathrm{~Hz}, 1 \mathrm{H}), 7.93(\mathrm{~s}, 1 \mathrm{H}), 11.28(\mathrm{~s}, 1 \mathrm{H})$; MS (ESI) $\left(\mathrm{MH}^{+}\right) 281.1$; MS (EMM) $\left(\mathrm{MH}^{+}\right)$calcd 281.0413, measured 281.0413.

\section{Thiophene-2-carboxaldehyde Tosylhydrazone}

White crystals, yield $83 \%$; mp $145-146{ }^{\circ} \mathrm{C}$ (lit. ${ }^{22} \mathrm{mp} 142-$ $\left.143.5^{\circ} \mathrm{C}\right) ;{ }^{1} \mathrm{H}$ NMR $\left(\mathrm{Me}_{2} \mathrm{SO}-d_{6}\right) \delta 2.29(\mathrm{~s}, 3 \mathrm{H}), 7.06(\mathrm{dd}, \mathrm{J}=4.9,3.6$ $\mathrm{Hz}, 1 \mathrm{H}), 7.35$ (dd, $J=3.5,1.1 \mathrm{~Hz}, 1 \mathrm{H}), 7.40(\mathrm{~d}, J=8.3 \mathrm{~Hz}, 2 \mathrm{H}), 7.59$ $(\mathrm{d}, J=4.1 \mathrm{~Hz}, 1 \mathrm{H}), 7.71(\mathrm{~d}, J=8.2 \mathrm{~Hz}, 2 \mathrm{H}), 8.08(\mathrm{~s}, 1 \mathrm{H}) ; \mathrm{MS}$ (ESI) $\left(\mathrm{MH}^{+}\right)$281.1; MS (EMM) $\left(\mathrm{MH}^{+}\right)$calcd 281.0413, measured 281.0410 .

\section{Furan-3-carboxaldehyde Tosylhydrazone}

Tan crystals, yield $36 \%$; mp $118-120{ }^{\circ} \mathrm{C}$ (lit. ${ }^{22} \mathrm{mp} 116-$ $\left.119{ }^{\circ} \mathrm{C}\right) ;{ }^{1} \mathrm{H}$ NMR $\left(\mathrm{Me}_{2} \mathrm{SO}-d_{6}\right) \delta 2.36(\mathrm{~s}, 3 \mathrm{H}), 6.62(\mathrm{~s}, 1 \mathrm{H}), 7.39(\mathrm{~d}, \mathrm{~J}=$ $8.1 \mathrm{~Hz}, 2 \mathrm{H}), 7.68(\mathrm{~s}, 1 \mathrm{H}), 7.73(\mathrm{~d}, \mathrm{~J}=8.1 \mathrm{~Hz}, 2 \mathrm{H}), 7.85(\mathrm{~s}, 1 \mathrm{H}), 8.02$ $(\mathrm{s}, 1 \mathrm{H}), 11.26(\mathrm{~s}, 1 \mathrm{H}) ; \mathrm{MS}(\mathrm{ESI})\left(\mathrm{MH}^{+}\right) 265.1 \mathrm{MS}(\mathrm{EMM})\left(\mathrm{MH}^{+}\right)$calcd 265.0642, measured 265.0638 .

\section{Furan-2-carboxaldehyde Tosylhydrazone}

Light tan crystals, yield $44 \%$; mp $113-115^{\circ} \mathrm{C}$ (lit. ${ }^{22} \mathrm{mp} 125-$ $\left.126{ }^{\circ} \mathrm{C}\right) ;{ }^{1} \mathrm{H}$ NMR $\left(\mathrm{Me}_{2} \mathrm{SO}-d_{6}\right) \delta 2.31(\mathrm{~s}, 3 \mathrm{H}), 6.55(\mathrm{dd}, J=3.3,1.9 \mathrm{~Hz}$, $1 \mathrm{H}), 6.79(\mathrm{~d}, J=3.2 \mathrm{~Hz}, 1 \mathrm{H}), 7.40(\mathrm{~d}, J=8.1 \mathrm{~Hz}, 2 \mathrm{H}), 7.71(\mathrm{~d}, J=$ $8.3 \mathrm{~Hz}, 2 \mathrm{H}), 7.76(\mathrm{~d}, J=1.6 \mathrm{~Hz}, 1 \mathrm{H}), 7.77(\mathrm{~s}, 1 \mathrm{H}), 11.43(\mathrm{~s}, 1 \mathrm{H})$; MS (ESI) $\left(\mathrm{MH}^{+}\right)$265.1; MS (EMM) $\left(\mathrm{MH}^{+}\right)$calcd 265.0642, measured 265.0654.

\section{Preparation of Tosylhydrazide Sodium Salts}

Sodium hydride ( 1.1 equiv, $60 \%$ suspension in mineral oil) was added to the corresponding tosylhydrazone ( 1 equiv) in THF and the 
mixture was allowed to stir at room temperature for $1 \mathrm{~h}$. The resulting precipitate was filtered and dried on a vacuum line. This reaction was run on a $500 \mathrm{mg}$ scale with respect to the tosylhydrazone.

\section{Preparation of Diazo Compounds 1-4}

The diazo compounds were generated by heating the corresponding tosylhydrazone sodium salts to $110^{\circ} \mathrm{C}$ under vacuum. The highly colored diazo compound was collected on a coldfinger at $-78{ }^{\circ} \mathrm{C}$ and rinsed into a deposition tube with $\mathrm{CH}_{2} \mathrm{Cl}_{2}$. After solvent removal under vacuum at $-41^{\circ} \mathrm{C}$, the diazo compound was deposited onto a cold window (IR, UV/vis) or copper rod (EPR) with a constant flow of argon or nitrogen. This procedure yielded the matrix isolated samples of diazo compounds $\mathbf{1}, \mathbf{2}, \mathbf{3}$, or $\mathbf{4}$.

\section{Procedure for Determining Extinction Coefficients for Diazo Compounds 1-4}

Diazo compounds 1-4 were formed via the procedure given above, but were rinsed from the coldfinger with $\mathrm{CD}_{3} \mathrm{CN}$ instead of $\mathrm{CH}_{2} \mathrm{Cl}_{2}$ to permit the use of ${ }^{1} \mathrm{H}$ NMR spectroscopy. An NMR sample was made with $1 \mathrm{~mL}$ of the original sample and the remaining sample was used to make stock solutions at varying concentrations. The NMR solution was spiked with a known amount of benzene to serve as an internal standard. This allowed the molar quantity of diazo compound to be determined, based upon the integration of the peaks in the spectrum. Finally, dividing the moles of diazo compound in the original sample by the $1 \mathrm{~mL}$ sample size used for NMR spectroscopy, the molarity of the original solution could be determined. The different stock solutions were used to determine $\lambda_{\max }$ in the visible and ultraviolet regions of the UV/vis spectrum and the Beer-Lambert law was used to determine extinction coefficients. Samples and solutions were kept in dry ice when they were not being used, in order to minimize decomposition. Solutions slowly warmed to room temperature during the course of NMR or UV/vis spectroscopic measurements.

Journal of the American Chemical Society, Vol 134, No. 14 (March 2012): pg. 6443-6454. DOI. This article is (C) American Chemical Society and permission has been granted for this version to appear in e-Publications@Marquette. American Chemical Society does not grant permission for this article to be further copied/distributed or hosted elsewhere without the express permission from American Chemical Society. 


\section{(3-Thienyl)diazomethane (1)}

Red liquid. UV/vis $\left(\mathrm{CH}_{3} \mathrm{CN}\right) \lambda_{\max }(\mathrm{nm})(\varepsilon)\left(\mathrm{L} \mathrm{mol}^{-1} \mathrm{~cm}^{-1}\right) 494$ (5.98), 260 (2820), 229 (2950), 192 (2010); IR (N, 10 K) 2065 s, 1597 w, 1544 w, 1534 w, 1435 w, 1404 w, 859 w, 841 w, 763 m, 709 w, 622 w, 485 w, $445 \mathrm{w} \mathrm{cm}^{-1} ;{ }^{1} \mathrm{H} \mathrm{NMR}\left(\mathrm{CD}_{3} \mathrm{CN}\right) \delta 5.31(\mathrm{~s}, 1 \mathrm{H}), 6.78$ $(\mathrm{dd}, J=1.3,5.0 \mathrm{~Hz}, 1 \mathrm{H}), 6.83(\mathrm{dd}, J=1.3,3.0 \mathrm{~Hz}, 1 \mathrm{H}), 7.44(\mathrm{dd}, J=$ 3.0, $5.0 \mathrm{~Hz}, 1 \mathrm{H})$.

\section{(2-Thienyl)diazomethane (2)}

Red liquid. UV/vis $\left(\mathrm{CH}_{3} \mathrm{CN}\right) \lambda_{\max }(\mathrm{nm})(\varepsilon)\left(\mathrm{L} \mathrm{mol}^{-1} \mathrm{~cm}^{-1}\right) 502$ (8.13), 297 (8620), 204 (6120); IR (Ar, 10 K) 2071 s, 1597 w, 1523 w, 1449 w, 1381 w, 1306 w, 1077 w, 803 w, 680 w cm ${ }^{-1}$; ${ }^{1} \mathrm{H}$ NMR $\left(\mathrm{CD}_{3} \mathrm{CN}\right) \delta 5.54(\mathrm{~s}, 1 \mathrm{H}), 6.86(\mathrm{dd}, J=1.0,3.5 \mathrm{~Hz}, 1 \mathrm{H}), 6.99(\mathrm{dd}, J=$ $3.5,5.0 \mathrm{~Hz}, 1 \mathrm{H}), 7.15(\mathrm{dd}, J=1.0,5.0 \mathrm{~Hz}, 1 \mathrm{H})$.

\section{(3-Furyl)diazomethane (3)}

Orange-red liquid. UV/vis $\left(\mathrm{CH}_{3} \mathrm{CN}\right) \lambda_{\max }(\mathrm{nm})(\varepsilon)\left(\mathrm{L} \mathrm{mol}^{-1} \mathrm{~cm}^{-1}\right)$ 491 (8.51), 251 (8050), 211 (5260); IR (Ar, 10 K) 2066 s, 1594 w, 1509 w, 1416 w, 1368 w, 1170 w, 1065 w, 1028 w, 874 w, 763 w, $589 \mathrm{w} \mathrm{cm}^{-1} ;{ }^{1} \mathrm{H}$ NMR $\left(\mathrm{CD}_{3} \mathrm{CN}\right) \delta 5.03(\mathrm{~s}, 1 \mathrm{H}), 6.29(\mathrm{~s}, 1 \mathrm{H}), 7.34(\mathrm{~m}$, $1 \mathrm{H}), 7.49$ ( $\mathrm{m}, 1 \mathrm{H}-$ very small coupling). (The NMR sample was spiked with a known quantity of benzene to enable the determination of the solution concentration of diazo compound. The ${ }^{1} \mathrm{H}$ NMR resonance of benzene interferes with the 7.34-ppm resonance of diazo compound $\mathbf{3}$, precluding an accurate determination of chemical shift/integration/coupling constant.)

\section{(2-Furyl)diazomethane (4)}

Orange-red liquid. UV/vis $\left(\mathrm{CH}_{3} \mathrm{CN}\right) \lambda_{\max }(\mathrm{nm})(\varepsilon)\left(\mathrm{L} \mathrm{mol}^{-1} \mathrm{~cm}^{-1}\right)$ 496 (16.3), 278 (10800); IR (Ar, 10 K) 2076 s, 1593 w, 1516 w, 1428 w, 1007 w, 927 w, 884 w, 767 w, 713 w, 657 w, 593 w cm ${ }^{-1} ;{ }^{1} \mathrm{H}$ NMR $\left(\mathrm{CD}_{3} \mathrm{CN}\right) \delta 5.36(\mathrm{~s}, 1 \mathrm{H}), 6.03(\mathrm{~d}, J=3.3 \mathrm{~Hz}, 1 \mathrm{H}), 6.45(\mathrm{dd}, J=2.0$, $3.3 \mathrm{~Hz}, 1 \mathrm{H}), 7.42(\mathrm{dd}, \mathrm{J}=0.7,2.0 \mathrm{~Hz}, 1 \mathrm{H})$. 
NOT THE PUBLISHED VERSION; this is the author's final, peer-reviewed manuscript. The published version may be accessed by following the link in the citation at the bottom of the page.

\section{Supporting Information}

Matrix-isolation spectra (IR, UV/vis, EPR) associated with the photolyses of diazo compounds 1-4; details concerning XSophe simulation of triplet EPR spectra; computed energies, harmonic vibrational frequencies, infrared intensities, and Cartesian coordinates of all computed structures. This material is available free of charge via the Internet at http://pubs.acs.org.

The authors declare no competing financial interest.

\section{Acknowledgment}

We gratefully acknowledge financial support from the National Science Foundation (NSF-1011959). We also acknowledge NSF support for Departmental facilities used in this research: EPR spectrometer (NSF9013030), computing facilities (NSF-0091916 and NSF-0840494), and NMR instrumentation (NSF-0342998). S.A.R. acknowledges a Way-Klingler sabbatical fellowship from Marquette University. We thank Prof. Thomas Brunold (UW-Madison) for assistance with the ORCA calculations.

\section{References}

${ }^{1}$ Wentrup, C. In Methoden der Organischen Chemie (Houben-Weyl); Regitz, M., Ed.; G. Thieme: Stuttgart, Germany, 1989; Vol. E19b, pp 8241021.

${ }^{2}$ Kinetics and Spectroscopy of Carbenes and Biradicals; Platz, M. S., Ed.; Plenum: New York, 1990.

${ }^{3}$ Reactive Intermediate Chemistry; Moss, R. A., Platz, M. S., Jones, M., Jr., Eds.; Wiley: Hoboken, NJ, 2004.

${ }^{4}$ Moss, R. A.; Turro, N. J. In Kinetics and Spectroscopy of Carbenes and Biradicals; Platz, M. S., Ed.; Plenum Press: New York, 1990, pp 213238.

${ }^{5}$ Jones, M., Jr.; Moss, R. A. In Reactive Intermediate Chemistry; Moss, R. A., Platz, M. S., Jones, M., Jr., Eds.; Wiley: Hoboken, NJ, 2004, pp 273328.

${ }^{6}$ Moss, R. A.; Jang, E. G.; Kim, H.-R.; Ho, G.-J.; Baird, M. S. Tetrahedron Lett. 1992, 33, 1427- 1430

${ }^{7}$ Khasanova, T.; Sheridan, R. S. J. Am. Chem. Soc. 1998, 120, 233- 234

${ }^{8}$ Khasanova, T.; Sheridan, R. S. Org. Lett. 1999, 1, 1091- 1093

${ }^{9}$ Baird, M. S.; Bruce, I. J. Chem. Res., Synop. 1990, 134- 135

Journal of the American Chemical Society, Vol 134, No. 14 (March 2012): pg. 6443-6454. DOI. This article is (C) American Chemical Society and permission has been granted for this version to appear in e-Publications@Marquette. American Chemical Society does not grant permission for this article to be further copied/distributed or hosted elsewhere without the express permission from American Chemical Society. 
NOT THE PUBLISHED VERSION; this is the author's final, peer-reviewed manuscript. The published version may be accessed by following the link in the citation at the bottom of the page.

${ }^{10}$ Moss, R. A.; Fu, X.; Ma, Y.; Sauers, R. R. Tetrahedron Lett. 2003, 44, 773776

${ }^{11}$ Khasanova, T.; Sheridan, R. S. J. Am. Chem. Soc. 2000, 122, 8585- 8586

${ }^{12}$ Nikitina, A.; Sheridan, R. S. J. Am. Chem. Soc. 2002, 124, 7670- 7671

${ }^{13}$ Nikitina, A. F.; Sheridan, R. S. Org. Lett. 2005, 7, 4467- 4470

${ }^{14}$ Wang, J.; Sheridan, R. S. Org. Lett. 2007, 9, 3177- 3180

${ }^{15}$ Kaiser, R. I. Chem. Rev. 2002, 102, 1309- 1358

${ }^{16}$ Albers, R.; Sander, W. J. Org. Chem. 1997, 62, 761- 764

${ }^{17}$ Albers, R.; Sander, W. Liebigs Ann./Recl. 1997, 897- 900

${ }^{18}$ Osaka, I.; McCullough, R. D. Acc. Chem. Res. 2008, 41, 1202- 1214

${ }^{19}$ Handbook of Thiophene-Based Materials: Applications in Organic Electronics and Photonics; Perepichka, I. F.; Perepichka, D. F., Eds.; Wiley: Chichester, UK, 2009.

${ }^{20}$ Sun, J.; Zhang, B.; Katz, H. E. Adv. Funct. Mater. 2011, 21, 29- 45

${ }^{21}$ Hoffman, R. V.; Shechter, H. J. Am. Chem. Soc. 1971, 93, 5940- 5941

${ }^{22}$ Hoffman, R. V.; Orphanides, G. G.; Shechter, H. J. Am. Chem. Soc. 1978, 100, 7927- 7933

${ }^{23}$ Pan, W.; Balci, M.; Shevlin, P. B. J. Am. Chem. Soc. 1997, 119, 5035- 5036

${ }^{24}$ McKee, M. L.; Shevlin, P. B.; Zottola, M. J. Am. Chem. Soc. 2001, 123, 9418- 9425

${ }^{25}$ Nakatani, K.; Adachi, K.; Tanabe, K.; Saito, I. J. Am. Chem. Soc. 1999, $121,8221-8228$

${ }^{26}$ McClintock, S. P.; Shirtcliff, L. D.; Herges, R.; Haley, M. M. J. Org. Chem. 2008, 73, 8755- 8762

${ }^{27}$ Shirtcliff, L. D.; McClintock, S. P.; Haley, M. M. Chem. Soc. Rev. 2008, 37, 343- 364

${ }^{28}$ Young, B. S.; Köhler, F.; Herges, R.; Haley, M. M. J. Org. Chem. 2011, 76, 8483- 8487

${ }^{29}$ Herges, R. Angew. Chem., Int. Ed. 1994, 33, 255- 273

${ }^{30}$ Sun, Y.; Wong, M. W. J. Org. Chem. 1999, 64, 9170- 9174

${ }^{31}$ Birney, D. M. J. Am. Chem. Soc. 2000, 122, 10917- 10925

${ }^{32}$ Seburg, R. A.; McMahon, R. J.; Stanton, J. F.; Gauss, J. J. Am. Chem. Soc. $1997,119,10838-10845$

${ }^{33}$ Plattner, D. A.; Houk, K. N. J. Am. Chem. Soc. 1995, 117, 4405- 4406

${ }^{34}$ Woodcock, H. L.; Schaefer, H. F.; Schreiner, P. R. J. Phys. Chem. A 2002, $106,11923-11931$

${ }^{35}$ Woodcock, H. L.; Moran, D.; Brooks, B. R.; Schleyer, P. v. R.; Schaefer, H. F. I. J. Am. Chem. Soc. 2007, 129, 3763- 3770

${ }^{36}$ Perrotta, R. R.; Winter, A. H.; Coldren, W. H.; Falvey, D. E. J. Am. Chem. Soc. $2011,133,15553-15558$

${ }^{37}$ Our ability to observe the IR absorption of triplet 3-thienylcarbene (13) relied on the use of a nitrogen matrix instead of an argon matrix. IR experiments carried out in argon failed to reveal any bands

Journal of the American Chemical Society, Vol 134, No. 14 (March 2012): pg. 6443-6454. DOI. This article is (C) American Chemical Society and permission has been granted for this version to appear in e-Publications@Marquette. American Chemical Society does not grant permission for this article to be further copied/distributed or hosted elsewhere without the express permission from American Chemical Society. 
attributable to the carbene, due to the unfortunate overlap between a strong absorption of 3-thienyldiazomethane (1) (disappearing) and the strongest absorption of triplet 3-thienylcarbene (13) (appearing). The nitrogen matrix shifts the peaks just enough that the absorption of carbene $\mathbf{1 3}$ can be observed.

${ }^{38}$ The IR bands of the minor species in the matrix are weak (Figure S1), and hence the comparison with the computed spectrum of $1 \mathrm{H}-2-$ thiabicyclo[3.1.0]hexa-3,5-diene (12) does not establish the structural assignment with a high degree of certainty. We therefore considered alternative structural assignments. 4-Thiacyclohexa-1,2,5-triene (7) is another low-energy isomer on the $\mathrm{C}_{5} \mathrm{H}_{4} \mathrm{~S}$ potential energy surface, but the computed IR spectrum of $\mathbf{7}$ exhibits poor agreement with the experimental IR bands (Figure S2). Each of the other $\mathrm{C}_{5} \mathrm{H}_{4} \mathrm{~S}$ isomers (Scheme 2) was also considered, but, in the end, the computed spectrum of 12 remained the most plausible assignment.

${ }^{39}$ Sander, W.; Bucher, G.; Wierlacher, S. Chem. Rev. 1993, 93, 1583- 1621 ${ }^{40}$ Trozzolo, A. M.; Wasserman, E. In Carbenes; Moss, R. A.; Jones, M., Jr., Eds.; Robert E. Krieger: Malabar, FL, 1983; Vol. II, pp 185- 206.

${ }^{41}$ Kirmse, W. Carbene Chemistry, 2nd ed.; Academic Press: New York, 1971. ${ }^{42}$ In this case, flash photolysis refers to shining high intensity (200 nm) light on the sample for $10 \mathrm{~s}, 30 \mathrm{~s}, 1 \mathrm{~min}$, or 5 min and taking a scan to see if carbene signal is produced. In the case of 3-thienyldiazomethane, there was no conversion to carbene under these conditions.

${ }^{43}$ LeBlanc, B. F.; Sheridan, R. S. J. Am. Chem. Soc. 1985, 107, 4554- 4556

${ }^{44}$ LeBlanc, B. F.; Sheridan, R. S. J. Am. Chem. Soc. 1988, 110, 7250- 7252

${ }^{45}$ Tomioka, H.; Suzuki, S.; Izawa, Y. J. Am. Chem. Soc. 1982, 104, 10471050

${ }^{46}$ Wang, J.; Burdzinski, G.; Gustafson, T. L.; Platz, M. S. J. Am. Chem. Soc. 2007, 129, 2597- 2606

${ }^{47}$ Matzinger, S.; Bally, T. J. Phys. Chem. A 2000, 104, 3544- 3552

${ }^{48}$ Zuev, P. S.; Sheridan, R. S.; Albu, T. V.; Truhlar, D. G.; Hrovat, D. A.; Borden, W. T. Science 2003, 299, 867- 870

${ }^{49}$ Schreiner, P. R.; Reisenauer, H. P.; Ley, D.; Gerbig, D.; Wu, C.-H.; Allen, W. D. Science 2011, 332, 1300- 1303

50McMahon, R. J. Science 2003, 299, 833- 834

${ }^{51}$ McMahon, R. J.; Chapman, O. L. J. Am. Chem. Soc. 1987, 109, 683- 692

${ }^{52}$ Bucher, G.; Sander, W. J. Org. Chem. 1992, 57, 1346- 1351

${ }^{53}$ In the article by McKee et al., the energy for singlet 2-thienylcarbene is computed for the $(s-Z)$ isomer, while the energy for triplet 2thienylcarbene is computed for the $(s-E)$ isomer. We noted this discrepancy when comparing our absolute energies to those reported in Table 1 of McKee's article, and we confirmed this interpretation by

Journal of the American Chemical Society, Vol 134, No. 14 (March 2012): pg. 6443-6454. DOI. This article is (C) American Chemical Society and permission has been granted for this version to appear in e-Publications@Marquette. American Chemical Society does not grant permission for this article to be further copied/distributed or hosted elsewhere without the express permission from American Chemical Society. 
NOT THE PUBLISHED VERSION; this is the author's final, peer-reviewed manuscript. The published version may be accessed by following the link in the citation at the bottom of the page.

inspecting the Cartesian coordinates provided in the Supporting Information supplied with the article.

${ }^{54}$ Aycard, J.-P.; Allouche, A.; Cossu, M.; Hillebrand, M. J. Phys. Chem. A 1999, 103, 9013-9021

${ }^{55}$ Hutton, R. S.; Roth, H. D.; Schilling, M. L. M.; Suggs, J. W. J. Am. Chem. Soc. $1981,103,5147-5151$

${ }^{56}$ Hutton, R. S.; Roth, H. D. J. Am. Chem. Soc. 1982, 104, 7395- 7399

${ }^{57}$ Roth, H. D.; Hutton, R. S. Tetrahedron 1985, 41, 1567- 1578

${ }^{58}$ Pharr, C. R. Ph.D. Dissertation, University of Wisconsin, 2008.

${ }^{59}$ Pharr, C. R.; McMahon, R. J., manuscript in preparation.

${ }^{60}$ Wasserman, E.; Snyder, L. C.; Yager, W. A. J. Chem. Phys. 1964, 41, 17631772

${ }^{61}$ Fontecave, M.; Ollagnier-de-Choudens, S.; Mulliez, E. Chem. Rev. 2003, 103, 2149- 2166

${ }^{62}$ Bolman, P. S. H.; Safarik, I.; Stiles, D. A.; Tyerman, W. J. R.; Strausz, O. P. Can. J. Chem. 1970, 48, 3872- 3876

${ }^{63}$ Sinnecker, S.; Neese, F. J. Phys. Chem. A 2006, 116, 12267- 12275

${ }^{64}$ Neese, F. J. Chem. Phys. 2007, 127, 164112

${ }^{65}$ Sander, W.; Grote, D.; Kossmann, S.; Neese, F. J. Am. Chem. Soc. 2008, $130,4396-4403$

${ }^{66}$ Grote, D.; Finke, C.; Kossmann, S.; Neese, F.; Sander, W. Chem.-Eur. J. 2010, 16, 4496- 4506

${ }^{67}$ McMahon, R. J.; Chapman, O. L.; Hayes, R. A.; Hess, T. C.; Krimmer, H.-P. J. Am. Chem. Soc. 1985, 107, 7597- 7606

${ }^{68}$ Seburg, R. A.; McMahon, R. J. J. Am. Chem. Soc. 1992, 114, 7183- 7189

${ }^{69}$ Frisch, M. J.Gaussian 09; Revision B.1, 2009.

70Purvis, G. D.; Bartlett, R. J. J. Chem. Phys. 1982, 76, 1910- 1918

${ }^{71}$ Dunning, T. H., Jr. J. Chem. Phys. 1989, 90, 1007- 1023

${ }^{72}$ Woon, D. E.; Dunning, T. H., Jr. J. Chem. Phys. 1993, 98, 1358- 1371

${ }^{73}$ Dunning, T. H., Jr.; Peterson, K. A.; Wilson, A. K. J. Chem. Phys. 2001, 114, 9244- 9253

${ }^{74}$ Stanton, J. F.; Gauss, J.; Harding, M. E.; Szalay, P. G.CFOUR, CoupledCluster Techniques for Computational Chemistry; with contributions from A. A. Auer, R. J. Bartlett, U. Benedikt, C. Berger, D. E. Bernholdt, Y. J. Bomble, L. Cheng, O. Christiansen, M. Heckert, O. Heun, C. Huber, T.-C. Jagau, D. Jonsson, J. Jusélius, K. Klein, W. J. Lauderdale, D. A. Matthews, T. Metzroth, D. P. O'Neill, D. R. Price, E. Prochnow, K. Ruud, F. Schiffmann, W. Schwalbach, S. Stopkowicz, A. Tajti, J. Vázquez, F. Wang, J. D. Watts and the integral packages: MOLECULE (J. Almlöf and P. R. Taylor), PROPS (P. R. Taylor), ABACUS (T. Helgaker, H. J. Aa. Jensen, P. Jørgensen, and J. Olsen), and ECP routines by $A$. V. Mitin, C. van Wüllen; www.cfour.de.

Journal of the American Chemical Society, Vol 134, No. 14 (March 2012): pg. 6443-6454. DOI. This article is (C) American Chemical Society and permission has been granted for this version to appear in e-Publications@Marquette. American Chemical Society does not grant permission for this article to be further copied/distributed or hosted elsewhere without the express permission from American Chemical Society. 
NOT THE PUBLISHED VERSION; this is the author's final, peer-reviewed manuscript. The published version may be accessed by following the link in the citation at the bottom of the page.

${ }^{75}$ Glendening, E. D.; Badenhoop, J. K.; Reed, A. E.; Carpenter, J. E.; Bohmann, J. A.; Morales, C. M.; Weinhold, F.NBO 5.0; Theoretical Chemistry Institute, University of Wisconsin: Madison, Wisconsin, 2001.

${ }^{76}$ Neese, F.; Wennmohs, F.; Becker, U.; Ganyushin, D.; Hansen, A.; Liakos, D. G.; Kollmar, C.; Kossmann, S.; Petrenko, T.; Reimann, C.; Riplinger, C.; Sivalingam, K.; Valeev, E.; Wezisla, B.ORCA, 2.8 ed. Lehrstuhl für Theoretische Chemie: Bonn, 2010; http://www.thch.unibonn.de/tc/orca/.

${ }^{77}$ Hanson, G. R.; Noble, C. J.; Benson, S. In High Resolution EPR: Application to Metalloenzymes and Metals in Medicine; Hanson, G.; Berliner, L., Eds.; Springer: Dordrecht, The Netherlands, 2009; Vol. 28, pp 105174.

${ }^{78}$ Katritzky, A. R.; Tymoshenko, D.; Nikonov, G. N. J. Org. Chem. 2001, 66, 4045- 4046

Journal of the American Chemical Society, Vol 134, No. 14 (March 2012): pg. 6443-6454. DOI. This article is (C) American Chemical Society and permission has been granted for this version to appear in e-Publications@Marquette. American Chemical Society does not grant permission for this article to be further copied/distributed or hosted elsewhere without the express permission from American Chemical Society. 